WSRC-TR-2003-00423

Revision 0

\title{
Characterization of Three Samples Taken From the Off Gas System
} of DWPF Melter One

Ned E. Bibler

Westinghouse Savannah River Company

Savannah River Site

Aiken, SC 29808

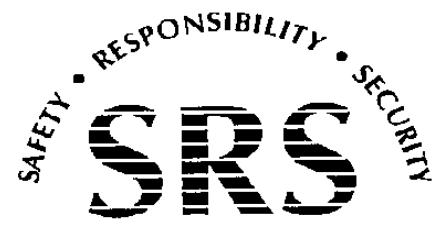

PREPARED FOR THE U.S. DEPARTMENT OF ENERGY UNDER CONTRACT NO. DE-AC09-96SR18500 
This document was prepared in conjunction with work accomplished under Contract No. DE-AC09-96SR18500 with the U. S. Department of Energy.

\section{DISCLAIMER}

This report was prepared as an account of work sponsored by an agency of the United States Government. Neither the United States Government nor any agency thereof, nor any of their employees, makes any warranty, express or implied, or assumes any legal liability or responsibility for the accuracy, completeness, or usefulness of any information, apparatus, product or process disclosed, or represents that its use would not infringe privately owned rights. Reference herein to any specific commercial product, process or service by trade name, trademark, manufacturer, or otherwise does not necessarily constitute or imply its endorsement, recommendation, or favoring by the United States Government or any agency thereof. The views and opinions of authors expressed herein do not necessarily state or reflect those of the United States Government or any agency thereof.

This report has been reproduced directly from the best available copy.

Available for sale to the public, in paper, from: U.S. Department of Commerce, National Technical Information Service, 5285 Port Royal Road, Springfield, VA 22161, phone: (800) 553-6847, fax: (703) 605-6900

email: orders@ntis.fedworld.gov

online ordering: http://www.ntis.gov/help/index.asp

Available electronically at http://www.osti.gov/bridge

Available for a processing fee to U.S. Department of Energy and its contractors, in paper, from: U.S. Department of Energy, Office of Scientific and Technical Information, P.O. Box 62, Oak Ridge, TN 37831-0062,

phone: (865)576-8401,

fax: (865)576-5728

email: $\underline{\text { reports@ adonis.osti.gov }}$ 
WSRC-TR-2003-00423

Revision 0

Keywords:

Melter One

Off Gas System

DWPF

Retention: Permanent

\section{Characterization of Three Samples Taken From the Off Gas System of DWPF Melter One}

Ned E. Bibler

Publication Date: September 30, 2003

Westinghouse Savannah River Company

Savannah River Site

Aiken, SC 29808

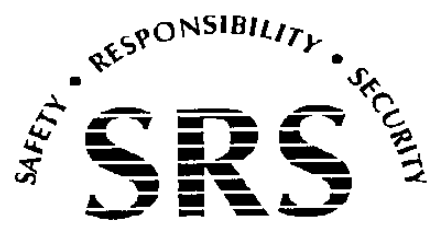

SAVANNAH RIVER SITE

PREPARED FOR THE U.S. DEPARTMENT OF ENERGY UNDER CONTRACT NO. DE-AC09-96SR18500 



\section{TABLE OF CONTENTS}

INTRODUCTION AND SUMMARY ...............................................................................................1

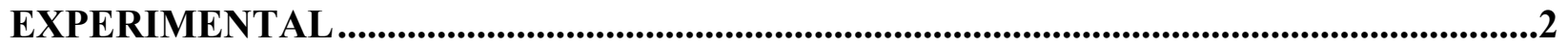

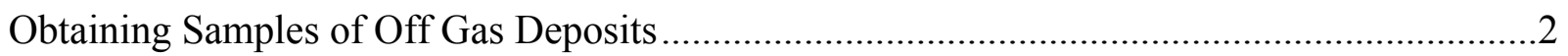

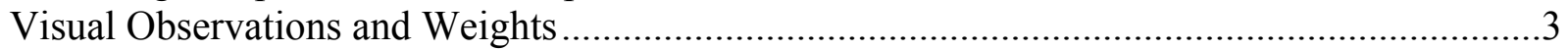

Composition of the Off Gas Samples …………………........................................................

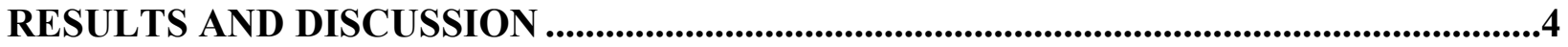

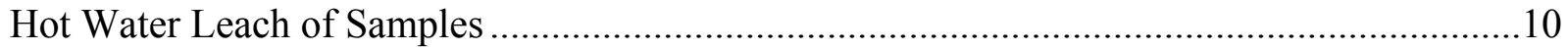

Contained X-Ray Diffraction Results ................................................................................13

Contained Scanning Electron Microscopy Results...................................................................15

CONCLUSIONS .................................................................................................................23

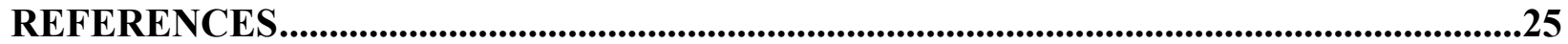

\section{LIST OF TABLES}

Table 1. Composition of Melter Off Gas Sample 0037 Taken ......................................................

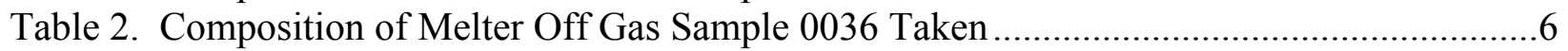

Table 3. Composition of Melter Off Gas Sample 0035 Taken From ..............................................

Table 4. Ratios of Concentrations of Selected Elements in the Off Gas Samples...........................

Table 5. Weight Percent of Elements and Anions Leached in Hot Water for the Off Gas Samples and the Fraction of Each Element Leached. .........................................................................12

\section{LIST OF FIGURES}

Figure 1. Locations in the DWPF Melter One Off Gas System of the Deposits Sampled (The PC designations for each sample indicate the primary containers that the samples were placed in for transport to SRTC.).

Figure 2. CXRD Pattern for Sample 0037 from the Primary Off Gas Line .................................14

Figure 3. CXRD Pattern for Sample 0036 from the Inlet to the Quencher ...................................14

Figure 4. CXRD Pattern for Sample 0035 from the Bottom of the Quencher................................15

Figure 5. Typical CSEM Micrograph for Sample 0037 from the Primary Off Gas Line..............16

Figure 6 Typical CSEM Micrograph for Sample 0036 from the Inlet to the Quencher................16

Figure 7. Typical CSEM Micrograph for Sample 0035 from the Bottom of the Quencher ..........17

Figure 8. An EDAX Spectrum for a Particle in Figure 5 for Sample 0037 from the Primary Off Gas Line. The element Fe is a major component. (The elements $\mathrm{Au}$ and $\mathrm{Pd}$ are from the conductive alloy put on the sample.) ......

Figure 9. An EDAX Spectrum for a Particle in Figure 5 for Sample 0037 from the Primary Off Gas Line. The element $\mathrm{S}$ is a major component. (The elements $\mathrm{Au}$ and $\mathrm{Pd}$ are from the conductive alloy put on the sample.).

Figure 10. An EDAX Spectrum for a Particle in Figure 6 for Sample 0036 from the Inlet to the Quencher The element Fe is a major component. (The elements Au and Pd are from the conductive alloy put on the sample.) 
Figure 11. An EDAX Spectrum for Another Particle in Figure 6 for Sample 0036 from the Inlet to the Quencher. The element Si is a major component. (The elements Au and Pd are from the conductive alloy put on the sample.)

Figure 12. An EDAX Spectrum for a Particle in Figure 7 for Sample 0035 from the Bottom of the Quencher. The element Fe is a major component. (The elements $\mathrm{Au}$ and $\mathrm{Pd}$ are from the conductive alloy put on the sample.)

Figure 13 An EDAX Spectrum for Another Particle in Figure 7 for Sample 0035 from the Bottom of the Quencher. The element Al is a major component. (The elements $\mathrm{Au}$ and $\mathrm{Pd}$ are from the conductive alloy put on the sample.)

\section{LIST OF ACRONYMS}

$\begin{array}{ll}\text { ADS } & \text { Analytical Development Section } \\ \text { CSEM } & \text { Contained Scanning Electron Microscopy } \\ \text { CXRD } & \text { Contained X-Ray Diffraction } \\ \text { DWPF } & \text { Defense Waste Processing Facility } \\ \text { EDAX } & \text { Energy Dispersive S-Ray Analysis } \\ \text { IC } & \text { Ion Chromatography } \\ \text { ICP-ES } & \text { Inductively Coupled Plasma Excitation Spectroscopy } \\ \text { ICP-MS } & \text { Inductively Coupled Plasma Mass Spectroscopy } \\ \text { PC } & \text { Primary Container } \\ \text { RSD } & \text { Relative Standard Deviation } \\ \text { SB } & \text { Sludge Batch } \\ \text { SRAT } & \text { Sludge Receipt Adjustment Tank } \\ \text { SRS } & \text { Savannah River Site } \\ \text { SRTC } & \text { Savannah River Technology Center } \\ \text { TRM } & \text { Telerobotic Manipulator }\end{array}$




\section{INTRODUCTION AND SUMMARY}

The first melter (Melter One) in the Defense Waste Processing Facility (DWPF) operated for more than eight years. It has been removed from service and replaced by Melter Two. For six of the eight years Melter One had been in radioactive operations immobilizing SRS high level waste sludges into a stable borosilicate glass for disposal in a geologic repository. Prior to DWPF radioactive operations there were two years of testing and qualification runs with nonradioactive simulated sludge.

During the eight years of DWPF operation an off gas system was attached to the melter to condense steam generated in the melter plenum and collect any entrained solids or volatilized species. This off gas system had been in operation during processing of Sludge Batches $1 \mathrm{~A}$ and 1B and a portion of Sludge Batch 2. During the replacement of Melter One in 2002, DWPF had the opportunity to take samples of three deposits from the off gas system. One of the three samples came from deposits in the off gas system just above the film cooler in the primary off gas line. Here the temperature was nominally $350-400^{\circ} \mathrm{C}$. [1] Thus there was no possibility of off gas condensate water contacting this deposit. The other two samples were taken from deposits at the inlet and the bottom of the quencher. Here the temperatures were $\sim 350^{\circ} \mathrm{C}$ and $<100^{\circ} \mathrm{C}$, respectively. These three samples of the deposits were taken on 11/18/02 and transported to SRTC on 5/8/03 for characterization.

The primary objective of this characterization was to determine if there was any evidence for the accumulation of fissile material relative to the element Fe in the deposits. Secondary objectives were to determine their chemical and crystalline compositions and determine what species could be leached from the deposits and appear in condensate water going to the SRS Tank Farm system. Results are summarized below.

- There was no evidence of accumulation of fissile material relative to Fe. The ratio of Fe to fissile material in the deposits was nominally 600 in the sample from the primary line and nominally 800 to 2000 in the deposits from the quencher. This ratio in Sludge Batch 2 (SB2) is 560 [2] and the critically safe ratio is 160 [3]).

- The chemical composition of the samples was a mixture of sludge and glass species. The element $\mathrm{Si}$ was a major component (14-20 weight percent) in all three deposits. The deposit from the primary line contained $\sim 12 \mathrm{wt} . \% \mathrm{Na}$, and $\sim 6 \% \mathrm{Fe}$ and $\mathrm{S}$. In the two deposits from the quencher, the $\mathrm{Na}$ and $\mathrm{S}$ were considerably lower and the $\mathrm{Fe}$ correspondingly higher. All the deposits contained U-235 fission products and actinide elements.

- From the chemical compositions, evidence was obtained for the some volatility of Cs137, Tc-99 and $\mathrm{Hg}$ from the melter. However, data obtained from the analysis of three glass samples from the melter during processing Sludge Batch 1A, indicate that $>93 \%$ of the Cs-137 and Tc-99 are retained in the molten glass and immobilized. [4] The element $\mathrm{Hg}$ is streamed stripped in the DWPF from the sludge prior to the vitrification process. It has been shown that $92 \%$ of the $\mathrm{Hg}$ can be removed by this process. [2]. Detection of $\mathrm{Hg}$ in the off gas system indicates that a small amount of $\mathrm{Hg}$ reaches the melter and is volatilized. 
- The chemical compositions of the samples also indicate that molten glass containing dissolved sludge is not getting from the melter into the off gas system where the samples were collected.

- A water leach test indicated that $93 \%$ of the S and $74 \%$ of the Na could be dissolved from the sample of deposits in the primary off gas line where the temperature was nominally $400^{\circ} \mathrm{C}$. A much lower percentage (10-20\%) from the deposits taken from the quencher. There was also evidence of B leaching from the deposits. These results are consistent with the extensive analyses of off gas deposits obtained from several melter campaigns performed during the development of the DWPF process. [5,6] In the present study the fraction of $\mathrm{Si}$ and $\mathrm{U}$ dissolved from all three deposits was only $\sim 1-2 \%$. The major anion leached was sulfate. This result suggests that one soluble species that may be going to the Tank Farm system from the melter off gas condensate water is sulfate, presumably $\mathrm{Na}_{2} \mathrm{SO}_{4}$. No soluble chlorides or fluorides were detected in the leachates from the off gas deposits.

- The primary crystalline compound in all three deposits was $\mathrm{Fe}_{2} \mathrm{O}_{3}$ consistent with the results in References 4 and 5. The deposit from the primary line also contained $\mathrm{Na}_{2} \mathrm{SO}_{4}$; however this compound was not present in the deposits from the quencher. No evidence was obtained for the presence of crystalline $\mathrm{NaCl}$. Not detecting crystalline $\mathrm{NaCl}$ is in contrast with results from analyses of deposits from off gas lines attached to melters used to develop the DWPF process.[5,6] However, the deposits taken in that study were taken further up the off gas line. Also the presence of $\mathrm{NaCl}$ in the off gas system would be very dependent on its concentration in the melter feed being processed.

- Examination by Scanning Electron Microscopy indicated that the deposits had primarily rounded particles rather than distinct crystals. Also the elements were not distributed uniformly throughout the deposits indicating that the deposits were mixtures of chemical compounds. This observation is also consistent with previous studies.[5,6]

\section{EXPERIMENTAL}

\section{Obtaining Samples of Off Gas Deposits}

Samples were taken from deposits at three different locations in the off gas system. They were obtained by suspending the primary off gas line and the quencher of the off gas system from the main process crane in the DWPF melt cell after the off gas line had been disconnected from Melter One. The samples were then obtained remotely. The telerobotic manipulator (TRM) was used to manipulate sharp-edged sample cups on the end of long rods to scrape samples from the areas of interest. These areas were the primary off gas line just past the film cooler, the inlet of the quencher, and the bottom of the quencher near its exit. Each sample was then poured from its sample cup into a new primary sample stainless steel container for transport to SRTC. The sampling location and the designation for the primary container (PC) for each sample are shown in Figure 1 
WSRC-TR-2003-00423

Revision 0

\section{PRIMARY OFFGAS LINE}
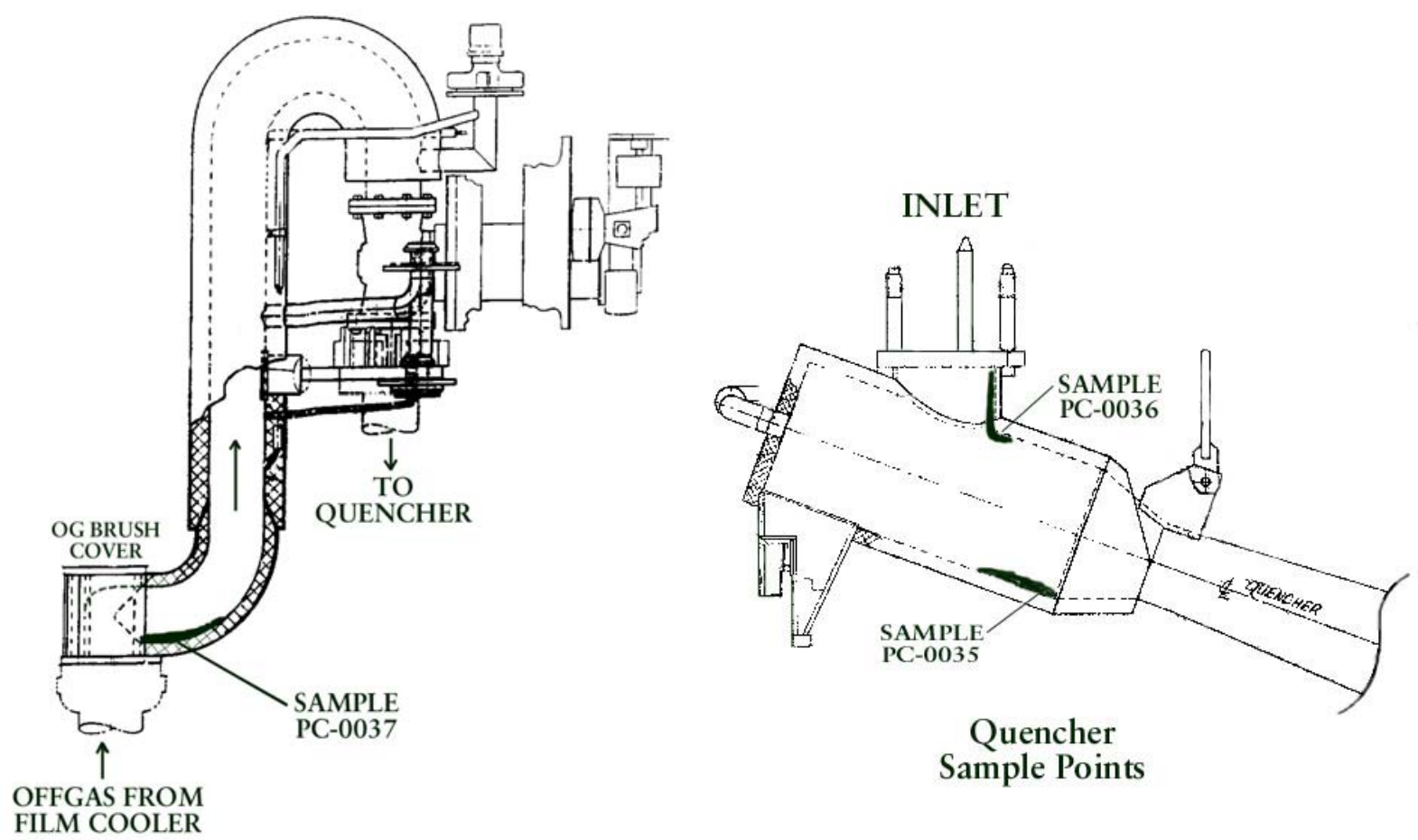

Figure 1. Locations in the DWPF Melter One Off Gas System of the Deposits Sampled (The PC designations for each sample indicate the primary containers that the samples were placed in for transport to SRTC.)

The sample from the primary off gas system just past the film cooler was placed into PC0037. The sample from the inlet to the quencher was placed into PC0036 and the sample from the bottom of the quencher into PC0035. The primary containers with their respective samples were then transported to SRTC. At SRTC the containers were placed in the Shielded Cells. Here they were opened and the samples removed and characterized.

\section{Visual Observations and Weights}

At SRTC the samples were poured from their primary containers into small weighed glass jars. The jars were then weighed again to obtain the weights of the samples. Throughout this report the samples will be designated by the number of their primary container. Sample 0036 from the inlet to the quencher weighed 7.211 grams. This sample was the easiest to obtain using the long rod attached to the TRM. The other two samples were more difficult to obtain and consequently smaller amounts of sample resulted. Sample 0035 from the bottom of the quencher and weighed 0.869 grams and Sample 0037 from the primary off gas line and weighed 0.837 grams. Visually, the appearances of the samples were identical. All were black and granular. They were primarily in small pieces with particle sizes ranging from approximately 0.5 to $8 \mathrm{~mm}$. The larger particles were easily broken with a micro spatula into smaller particles. These larger particles 
were broken up but no attempt was made to grind and homogenize the samples. They were just mixed in the jars by using the micro spatula held by the manipulator.

\section{Composition of the Off Gas Samples}

Small amounts of each sample were dissolved remotely in sealed Teflon vessels by the mixed acid technique developed by the Analytical Development Section (ADS) of SRTC. [7] This method is used to dissolve DWPF glass and uses a mixture of $\mathrm{HF}, \mathrm{HNO}_{3}$, and $\mathrm{HCl}$ acids. Boron is used in the method; thus the element cannot be determined by this method. The mixed acid method was chosen to ensure that any silicates that may be in the samples were dissolved. Teflon vessels that could be tightly sealed were used to ensure that any elements volatilized during the procedure such as $\mathrm{Hg}$ were retained in the solutions during the dissolution. At the end of the dissolution procedure there were no visible solids in any of the acid solutions indicating that the entire amount of each sample had been dissolved. A standard glass was dissolved and analyzed with the samples to check if the dissolutions were performed correctly and the analyses were accurate. Results for the standard glass indicated that this was the case. A blank dissolution (no sample was present) was also performed to check for impurities in the reagents or radioactive contamination that might have resulted from performing the dissolutions remotely in the Shielded Cells. Results of the blank indicated that concentrations of impurities and contaminants were negligible compared to concentrations of the analytes measured.

For Samples 0035 and 0037 only small amounts ( 0.1 grams) of duplicate samples were dissolved because of the limited amount of sample obtained. For Sample 0036 where a larger amount of off gas sample was obtained, triplicate samples were dissolved, two weighing $\sim 0.1$ grams and one weighing 0.25 grams as called for in the procedure [5]. Aliquots of the resulting solutions were removed from the Shielded Cells and submitted to ADS for analysis. They were analyzed by Inductively Coupled Plasma Excitation Spectroscopy (ICP-ES) for elemental concentrations, Inductively Coupled Plasma Mass Spectroscopy (ICP-MS) for U-235 fission products and actinides, and counting techniques for gamma emitters and Sr-90.

\section{RESULTS AND DISCUSSION}

Results for the compositions of the three off gas samples are in Tables 1, 2, and 3. Each Table, gives the concentrations measured in the individual samples, the average of the two or three replicates and the percent relative standard deviation (\%RSD) of the results.

Results for the three off gas samples are in Tables 1, 2, and 3. Each Table, gives the concentrations measured in the individual samples, the average of the two or three replicates and the percent relative standard deviation $(\% \mathrm{RSD})$ of the results. 
Table 1. Composition of Melter Off Gas Sample 0037 Taken from the Primary Off Gas Line of the Melter

Elements Measured by ICP-ES

Concentrations are given in weight percent.

\begin{tabular}{cccccc} 
Element & $\mathbf{0 0 3 7 - 1 ( a )}$ & $\mathbf{0 0 3 7 - 2 ( b )}$ & & Average & \%RSD \\
\cline { 1 - 3 } \cline { 5 - 6 } $\mathbf{A g}$ & 0.08 & 0.07 & & 0.08 & 9.5 \\
$\mathbf{A l}$ & 1.21 & 1.25 & & 1.23 & 2.6 \\
$\mathbf{C a}$ & 0.63 & 0.62 & & 0.62 & 1.5 \\
$\mathbf{C d}$ & 0.48 & 0.42 & & 0.45 & 9.1 \\
$\mathbf{C r}$ & 0.16 & 0.20 & & 0.18 & 12 \\
$\mathbf{C u}$ & 0.01 & 0.01 & & 0.01 & 0.4 \\
$\mathbf{F e}$ & 5.11 & 5.14 & & 5.13 & 0.4 \\
$\mathbf{H g}$ & $<0.01$ & ND & & ND & ND \\
$\mathbf{L i}$ & 0.34 & 0.37 & & 0.34 & 7.4 \\
$\mathbf{M g}$ & 0.46 & 0.48 & & 0.46 & 3.5 \\
$\mathbf{M n}$ & 0.74 & 0.75 & & 0.75 & 0.8 \\
$\mathbf{N a}$ & 11.43 & 12.08 & & 11.75 & 3.9 \\
$\mathbf{N i}$ & 0.18 & 0.26 & & 0.22 & 26 \\
$\mathbf{S}$ & 6.82 & 6.45 & & 6.64 & 3.9 \\
$\mathbf{S i}$ & 20.00 & 18.30 & & 19.15 & 6.3 \\
$\mathbf{S n}$ & 0.26 & 0.21 & 0.24 & 13 \\
$\mathbf{S r}$ & 0.13 & 0.13 & 0.13 & 1.9 \\
$\mathbf{U}$ & 1.24 & 1.21 & 1.22 & 1.8
\end{tabular}

Radionuclides Measured by Gamma Beta Counting

Concentrations are given in microcuries/gram.

$\begin{array}{crrrr}\text { Sr-90 } & 9.40 \mathrm{E}+02 & 9.22 \mathrm{E}+02 & 9.31 \mathrm{E}+02 & 1.3 \\ \mathbf{C s}-\mathbf{1 3 7} & 2.71 \mathrm{E}+03 & 2.40 \mathrm{E}+03 & 2.56 \mathrm{E}+03 & 8.8\end{array}$

Isotopes Measured by ICP-MS

Concentrations are given in weight percent.

$\begin{array}{ccccc}\text { Tc-99 } & 1.19 \mathrm{E}-02 & 1.30 \mathrm{E}-02 & 1.25 \mathrm{E}-02 & 6.1 \\ \text { Mo-100 } & 7.06 \mathrm{E}-04 & 9.94 \mathrm{E}-04 & 8.50 \mathrm{E}-04 & 24 \\ \text { Ru-101 } & 4.70 \mathrm{E}-03 & 5.92 \mathrm{E}-03 & 5.31 \mathrm{E}-03 & 16 \\ \text { Ru-102 } & 3.94 \mathrm{E}-03 & 5.13 \mathrm{E}-03 & 4.53 \mathrm{E}-03 & 19 \\ \text { Rh-103 } & 1.73 \mathrm{E}-03 & 1.69 \mathrm{E}-03 & 1.71 \mathrm{E}-03 & 1.9 \\ \text { Ru-104 } & 2.34 \mathrm{E}-03 & 3.04 \mathrm{E}-03 & 2.69 \mathrm{E}-03 & 19 \\ \text { Pd-105 } & 9.93 \mathrm{E}-05 & 1.34 \mathrm{E}-04 & 1.17 \mathrm{E}-04 & 21 \\ \text { U-233 } & 5.08 \mathrm{E}-05 & 5.22 \mathrm{E}-05 & 5.15 \mathrm{E}-05 & 1.9 \\ \text { U-234 } & 1.46 \mathrm{E}-04 & 1.42 \mathrm{E}-04 & 1.44 \mathrm{E}-04 & 2.1 \\ \text { U-235 } & 5.85 \mathrm{E}-03 & 5.75 \mathrm{E}-03 & 5.80 \mathrm{E}-03 & 1.3 \\ \text { U-236 } & 4.12 \mathrm{E}-04 & 3.76 \mathrm{E}-04 & 3.94 \mathrm{E}-04 & 6.4 \\ \text { Np-237 } & 3.81 \mathrm{E}-04 & 2.96 \mathrm{E}-04 & 3.39 \mathrm{E}-04 & 18 \\ \text { U-238 } & 1.32 \mathrm{E}+00 & 1.42 \mathrm{E}+00 & 1.37 \mathrm{E}+00 & 5.2 \\ \text { Pu-239 } & 2.73 \mathrm{E}-03 & 2.54 \mathrm{E}-03 & 2.63 \mathrm{E}-03 & 5.1 \\ \text { Pu-240 } & 2.21 \mathrm{E}-04 & 2.05 \mathrm{E}-04 & 2.13 \mathrm{E}-04 & 5.3 \\ \text { Am-241 } & 1.08 \mathrm{E}-04 & 9.66 \mathrm{E}-05 & 1.02 \mathrm{E}-04 & 7.8\end{array}$

(a) 0.105 grams dissolved and diluted to $100 \mathrm{~mL}$

(b) 0.106 grams dissolved and diluted to $100 \mathrm{~mL}$. 
Table 2. Composition of Melter Off Gas Sample 0036 Taken from the Inlet to the Quencher on the Off Gas Line of the Melter

Elements Measured by ICP-ES

Concentrations are given in weight percent.

Element $0036-1$ (a) $0036-2$ (b) $0036-3$ (c)

$\begin{array}{clll}\mathbf{A g} & 0.01 & 0.01 & 0.01 \\ \mathbf{A l} & 3.40 & 3.25 & 2.47 \\ \mathbf{C a} & 0.45 & 0.54 & 0.42 \\ \mathbf{C d} & 0.15 & 0.16 & 0.13 \\ \mathbf{C r} & 0.18 & 0.14 & 0.16 \\ \mathbf{C u} & 0.02 & 0.02 & 0.02 \\ \mathbf{F e} & 18.5 & 17.5 & 20.6 \\ \mathbf{H g} & 0.52 & \mathrm{ND} & \mathrm{ND} \\ \mathbf{L i} & 0.17 & 0.14 & 0.16 \\ \mathbf{M g} & 0.60 & 0.57 & 0.57 \\ \mathbf{M n} & 1.93 & 1.95 & 1.55 \\ \mathbf{N a} & 1.06 & 0.78 & 1.12 \\ \mathbf{N i} & 0.42 & 0.38 & 0.30 \\ \mathbf{S} & 1.09 & 1.12 & 1.38 \\ \mathbf{S i} & 19.9 & 19.9 & 19.9 \\ \mathbf{S n} & 0.29 & 0.23 & 0.32 \\ \mathbf{S r} & 0.09 & 0.12 & 0.09 \\ \mathbf{U} & 1.84 & 1.55 & 1.82\end{array}$

\begin{tabular}{cc} 
Average & \%RSD \\
\hline 0.01 & 19 \\
3.04 & 16 \\
0.47 & 13 \\
0.15 & 10 \\
0.16 & 12 \\
0.02 & 9.3 \\
18.9 & 8.3 \\
ND & ND \\
0.17 & 9.1 \\
0.60 & 2.7 \\
1.81 & 13 \\
0.99 & 18 \\
0.37 & 17 \\
1.20 & 14 \\
18.9 & 6.5 \\
0.28 & 17 \\
0.10 & 17 \\
1.74 & 9.5
\end{tabular}

$\underline{\text { Radionuclides Measured by Beta or Gamma Counting }}$

Concentrations are given in microcuries/gram.

$\begin{array}{crrrrr}\text { Sr-90 } & 9.83 \mathrm{E}+02 & 7.24 \mathrm{E}+02 & 7.66 \mathrm{E}+02 & 8.25 \mathrm{E}+02 & 17 \\ \text { Cs-137 } & 2.77 \mathrm{E}+02 & 3.19 \mathrm{E}+02 & 2.58 \mathrm{E}+02 & 2.84 \mathrm{E}+02 & 11\end{array}$

Isotopes Measured by ICP-MS

Concentrations are given in weight percent.

$\begin{array}{cccccc}\text { Tc-99 } & 2.74 \mathrm{E}-03 & 2.55 \mathrm{E}-03 & 2.07 \mathrm{E}-03 & 2.45 \mathrm{E}-03 & 14 \\ \text { Mo-100 } & 6.59 \mathrm{E}-03 & 4.06 \mathrm{E}-03 & 4.21 \mathrm{E}-03 & 4.95 \mathrm{E}-03 & 29 \\ \text { Ru-101 } & 1.02 \mathrm{E}-01 & 3.24 \mathrm{E}-02 & 3.75 \mathrm{E}-02 & 5.73 \mathrm{E}-02 & 68 \\ \text { Ru-102 } & 8.49 \mathrm{E}-02 & 2.82 \mathrm{E}-02 & 3.19 \mathrm{E}-02 & 4.83 \mathrm{E}-02 & 66 \\ \text { Rh-103 } & 5.77 \mathrm{E}-03 & 5.80 \mathrm{E}-03 & 4.15 \mathrm{E}-03 & 5.24 \mathrm{E}-03 & 18 \\ \text { Ru-104 } & 4.70 \mathrm{E}-02 & 1.70 \mathrm{E}-02 & 1.77 \mathrm{E}-02 & 2.72 \mathrm{E}-02 & 63 \\ \text { Pd-105 } & 7.57 \mathrm{E}-04 & 2.71 \mathrm{E}-04 & 2.46 \mathrm{E}-04 & 4.25 \mathrm{E}-04 & 68 \\ \text { U-233 } & 9.76 \mathrm{E}-05 & 1.21 \mathrm{E}-04 & 6.85 \mathrm{E}-05 & 9.56 \mathrm{E}-05 & 27 \\ \text { U-234 } & 1.79 \mathrm{E}-04 & 1.88 \mathrm{E}-04 & 1.43 \mathrm{E}-04 & 1.70 \mathrm{E}-04 & 14 \\ \text { U-235 } & 6.77 \mathrm{E}-03 & 6.74 \mathrm{E}-03 & 6.22 \mathrm{E}-03 & 6.57 \mathrm{E}-03 & 4.7 \\ \text { U-236 } & 4.83 \mathrm{E}-04 & 5.32 \mathrm{E}-04 & 3.85 \mathrm{E}-04 & 4.67 \mathrm{E}-04 & 16 \\ \text { Np-237 } & 2.56 \mathrm{E}-04 & 3.36 \mathrm{E}-04 & 2.85 \mathrm{E}-04 & 1.43 \mathrm{E}+00 & 2.3 \\ \text { U-238 } & 1.47 \mathrm{E}+00 & 1.42 \mathrm{E}+00 & 1.40 \mathrm{E}+00 & 4.32 \mathrm{E}-03 & 19 \\ \text { Pu-239 } & 3.48 \mathrm{E}-03 & 5.08 \mathrm{E}-03 & 4.39 \mathrm{E}-03 & 3.43 \mathrm{E}-04 & 20 \\ \text { Pu-240 } & 2.90 \mathrm{E}-04 & 4.21 \mathrm{E}-04 & 3.18 \mathrm{E}-04 & 1.83 \mathrm{E}-04 & 39 \\ \text { Am-241 } & 1.01 \mathrm{E}-04 & 2.32 \mathrm{E}-04 & 2.15 \mathrm{E}-04 & & 14\end{array}$

(a) 0.244 grams dissolved and diluted to $250 \mathrm{~mL}$.

(b) 0.102 grams dissolved and diluted to $100 \mathrm{~mL}$.

(c) 0.097 grams dissolved and diluted to $100 \mathrm{~mL}$ 
Table 3. Composition of Melter Off Gas Sample 0035 Taken From the Bottom of the Quencher on the Off Gas Line of the Melter

Elements Measured by ICP-ES

Concentrations are given in weight percent.

\begin{tabular}{|c|c|c|c|c|}
\hline Element & $0035-1(a)$ & $0035-2$ (b) & Average & $\%$ RSD \\
\hline Ag & 0.02 & 0.01 & 0.02 & 9.0 \\
\hline Al & 5.38 & 4.45 & 4.92 & 13 \\
\hline $\mathrm{Ca}$ & 0.68 & 0.51 & 0.59 & 19 \\
\hline Cd & 0.13 & 0.12 & 0.13 & 2.9 \\
\hline $\mathrm{Cr}$ & 0.15 & 0.15 & 0.15 & 0.1 \\
\hline $\mathrm{Cu}$ & 0.02 & 0.02 & 0.02 & 14 \\
\hline $\mathrm{Fe}$ & 17.2 & 20.6 & 18.9 & 12.7 \\
\hline Hg & 0.77 & ND & ND & ND \\
\hline $\mathbf{L i}$ & 0.15 & 0.12 & 0.15 & 11 \\
\hline Mg & 0.97 & 0.71 & 0.97 & 19 \\
\hline Mn & 2.76 & 2.73 & 2.75 & 0.7 \\
\hline $\mathbf{N a}$ & 0.98 & 0.85 & 0.91 & 10 \\
\hline $\mathbf{N i}$ & 0.44 & 0.40 & 0.42 & 6.4 \\
\hline $\mathbf{S}$ & 1.28 & 1.02 & 1.15 & 16 \\
\hline $\mathbf{S i}$ & 14.1 & 14.1 & 14.1 & 0.1 \\
\hline Sn & 0.27 & 0.31 & 0.29 & 7.8 \\
\hline $\mathrm{Sr}$ & 0.15 & 0.11 & 0.13 & 19 \\
\hline $\mathbf{U}$ & 3.19 & 2.31 & 2.75 & 23 \\
\hline
\end{tabular}

Radionuclides Measured by Beta or Gamma Counting

Concentrations are given in microcuries/gram.

$\begin{array}{ccccc}\text { Sr-90 } & 1.34 \mathrm{E}+03 & 8.50 \mathrm{E}+02 & 1.09 \mathrm{E}+03 & 32 \\ \mathbf{C s - 1 3 7} & 4.25 \mathrm{E}+02 & 4.25 \mathrm{E}+02 & 4.25 \mathrm{E}+02 & 0.0\end{array}$

Isotopes Measured by ICP-MS

Concentrations are given in weight percent.

$\begin{array}{ccccc}\text { Tc-99 } & 4.35 \mathrm{E}-03 & 4.66 \mathrm{E}-03 & 4.50 \mathrm{E}-03 & 5.0 \\ \text { Mo-100 } & 2.23 \mathrm{E}-03 & 2.31 \mathrm{E}-03 & 2.27 \mathrm{E}-03 & 2.3 \\ \text { Ru-101 } & 2.90 \mathrm{E}-03 & 3.43 \mathrm{E}-03 & 3.16 \mathrm{E}-03 & 12 \\ \text { Ru-102 } & 3.45 \mathrm{E}-02 & 4.20 \mathrm{E}-02 & 3.83 \mathrm{E}-02 & 14 \\ \text { Rh-103 } & 2.99 \mathrm{E}-02 & 3.54 \mathrm{E}-02 & 3.26 \mathrm{E}-02 & 12 \\ \text { Ru-104 } & 5.87 \mathrm{E}-03 & 7.18 \mathrm{E}-03 & 6.52 \mathrm{E}-03 & 14 \\ \text { Pd-105 } & 1.74 \mathrm{E}-02 & 1.95 \mathrm{E}-02 & 1.84 \mathrm{E}-02 & 8.1 \\ \mathbf{U - 2 3 3} & 2.09 \mathrm{E}-04 & 1.31 \mathrm{E}-04 & 1.70 \mathrm{E}-04 & 32 \\ \mathbf{U - 2 3 4} & 3.81 \mathrm{E}-04 & 2.59 \mathrm{E}-04 & 3.20 \mathrm{E}-04 & 27 \\ \mathbf{U - 2 3 5} & 1.38 \mathrm{E}-02 & 9.34 \mathrm{E}-03 & 1.15 \mathrm{E}-02 & 27 \\ \mathbf{U - 2 3 6} & 9.90 \mathrm{E}-04 & 6.76 \mathrm{E}-04 & 8.33 \mathrm{E}-04 & 27 \\ \text { Np-237 } & 5.38 \mathrm{E}-04 & 3.81 \mathrm{E}-04 & 4.59 \mathrm{E}-04 & 24 \\ \text { U-238 } & 3.18 \mathrm{E}+00 & 2.15 \mathrm{E}+00 & 2.67 \mathrm{E}+00 & 27 \\ \text { Pu-239 } & 5.74 \mathrm{E}-03 & 6.17 \mathrm{E}-03 & 5.96 \mathrm{E}-03 & 5.1 \\ \text { Pu-240 } & 4.10 \mathrm{E}-04 & 4.98 \mathrm{E}-04 & 4.54 \mathrm{E}-04 & 14 \\ \text { Am-241 } & 2.52 \mathrm{E}-04 & 1.70 \mathrm{E}-04 & 2.11 \mathrm{E}-04 & 27\end{array}$

(a) 0.104 grams dissolved and diluted to $100 \mathrm{~mL}$.

(b) 0.097 grams dissolved and diluted to $100 \mathrm{~mL}$. 
The results in Tables 1-3 indicate that all the samples of off gas deposits contain the major components in the radioactive sludge and glass frit along with U-235 fission products and actinides. In all three deposits, $\mathrm{Si}$ is a major component (14 to 20 weight percent).

In Table 1 it can be seen that the agreement between the results for major elements measured by ICP-ES for Sample 0037 is within nominally 5\% or better. However the agreement in the other two samples as shown in Tables 2 and 3 is not as as good (10-20\% RSR). This trend is also indicated for the minor elements measured by beta-gamma counting or by ICP-MS. When quadruplicate glass samples from the DWPF melter are ground and dissolved the agreement between the results especially for the major elements is usually $5 \%$ or better.[8] The disagreement between replicate samples from the deposits is not unexpected because it has been shown that off gas deposits are agglomerates of compounds rather than a homogeneous mixture.[5,6] The data in the three Tables does show that the composition of Sample 0037 is different from the other two in that Sample 0037 contains relative high concentrations of $\mathrm{Na}$ and $\mathrm{S}$ compared to the other two samples. Also Hg was detected and measured in Samples 0036 and 0035 and not detected in Sample 0037. Further information can be obtained by comparing ratios of concentrations of elements in each sample with their respective ratios in actual sludge.

By comparing the ratios of different elements in the off gas samples with respective ratios in the sludge that was processed in Melter One, information can be obtained concerning whether certain elements are enhanced in the off gas samples. This can indicate whether the ratio of Fe to fissile material is different in the off gas samples compared to the melter feed and whether there is volatility of any elements from the melter. Table 4 shows calculated ratios of selected elements or isotopes in the off gas samples compared to their respective ratios calculated from concentrations measured for the selected species in SB2.[2,9] Even though the off gas system had been on the melter while processing SB1A, SB1B, and a portion of SB2, SB 2 was chosen for this comparison because it was the last sludge being processed before the melter was removed. For the off gas samples, results of individual dissolved samples rather than averages were used to calculate the ratios because of the inhomogeneity of the samples. The concentrations of all the elements except Cs-137 and Sr-90 are given in weight percent. For the radionuclides $\mathrm{Cs}-137$ and $\mathrm{Sr}-90$ the concentrations are microcuries per gram of sample. The concentrations used to calculate the ratios for SB2 elements are given in References 2 and 9. 
WSRC-TR-2003-00423

Revision 0

Table 4. Ratios of Concentrations of Selected Elements in the Off Gas Samples Compared to Their Respective Ratios in Sludge Batch 2

\begin{tabular}{|c|c|c|c|c|c|c|c|c|}
\hline \multirow[t]{2}{*}{ Ratio (a) } & \multicolumn{7}{|c|}{ Off Gas Samples } & \multirow{2}{*}{$\begin{array}{c}\text { SB2 } \\
\text { Sludge(b) }\end{array}$} \\
\hline & $0037-1$ & $0037-2$ & 0036-1 & 0036-2 & 0036-3 & 0035-1 & 0035-2 & \\
\hline $\mathrm{Fe} / \mathrm{Al}$ & 4.2 & 4.1 & 5.5 & 5.4 & 8.3 & 3.2 & 4.6 & 4.1 \\
\hline Fe/Sr-90 & $1.8 \mathrm{E}+02$ & $1.8 \mathrm{E}+02$ & $5.3 \mathrm{E}+01$ & $4.1 \mathrm{E}+01$ & $3.7 \mathrm{E}+01$ & $7.8 \mathrm{E}+01$ & $4.1 \mathrm{E}+01$ & $1.9 \mathrm{E}+02$ \\
\hline $\mathrm{Fe} / \mathbf{U}$ & 4.1 & 4.3 & 10.1 & 11.3 & 11.3 & 5.4 & 8.9 & 3.1 \\
\hline $\mathrm{Fe} /(\mathrm{U} 233+\mathrm{Pu}-239+\mathrm{U}-235)(\mathrm{c})$ & 593 & 617 & 1792 & 1470 & 1933 & 873 & 1318 & 560 \\
\hline $\mathrm{Hg} / \mathrm{Fe}$ & $<2.0 \mathrm{E}-03$ & NA & NA & $2.8 \mathrm{E}-02$ & NA & $4.5 \mathrm{E}-02$ & NA & 7.4E-04(d) \\
\hline Cs-137/Fe & 531 & 466 & 14.9 & 18.2 & 12.5 & 24.7 & 20.6 & 12.0 \\
\hline Cs-137/Sr-90 & 2.89 & 2.60 & 0.281 & 0.440 & 0.336 & 0.318 & 0.500 & 0.061 \\
\hline Tc-99/Fe & $2.3 \mathrm{E}-03$ & $2.5 \mathrm{E}-03$ & $1.5 \mathrm{E}-04$ & $1.5 \mathrm{E}-04$ & $1.0 \mathrm{E}-04$ & $1.3 \mathrm{E}-04$ & 2.3E-04 & $3.1 \mathrm{E}-05$ \\
\hline Tc-99/Sr-90 & $1.3 \mathrm{E}-05$ & $1.4 \mathrm{E}-05$ & $2.8 \mathrm{E}-06$ & $3.5 \mathrm{E}-06$ & 2.7E-06 & $1.7 \mathrm{E}-06$ & $5.5 \mathrm{E}-06$ & $1.6 \mathrm{E}-07$ \\
\hline $\mathbf{F e} / \mathbf{S i}$ & 3.9 & 3.6 & 1.1 & 1.1 & 0.85 & 0.82 & 0.69 & 19.8 \\
\hline $\mathbf{L i} / \mathbf{S i}$ & 0.017 & 0.020 & 0.008 & 0.007 & 0.009 & 0.010 & 0.009 & $0.069(\mathrm{e})$ \\
\hline
\end{tabular}

(a) The ratios that have Sr-90 and Cs-137 concentrations in them have $\mathrm{uCi} / \mathrm{g}$ for concentrations of these radionuclides and weight percent for concentrations of the other elements in the ratios.

(b) Calculated from data published in References 2 and 9.

(c) The fissile element Pu-241 was not measured but based on analyses of other SB2 (see Ref.9) and its short half life (15y) its concentration is expected to have negligible effect on this ratio.

(d) This is the ratio of $\mathrm{Hg}$ to $\mathrm{Fe}$ in the SRAT product of the SRAT qualification run performed at SRTC. See Reference 2.

(e) This is the ratio of Li to Si in Frit 200. See Reference 8.

The ratios of $\mathrm{Fe}$ to $\mathrm{Al}$ in four of the five off gas samples agree fairly well with that in SB2. This implies that the deposits are entrained sludge or glass particles and that there is no segregation between these two elements during entrainment in the off gas. These particles are splashed, volatilized carried from the melter surface and then caught in the off gas stream. This also indicates that the $\mathrm{Fe}$ present in the samples did not result from $\mathrm{Fe}$ or its corrosion products being scraped off the off gas system itself by the sharp edged sampling cup attached to the TRM. Scraping of $\mathrm{Fe}$ or its corrosion products from the quencher could be hypothesized as a possible reason for the high ratio in Sample 0036-3. However the quencher is made of an Allcorr alloy that does not contain Fe.[10] The primary off gas line at the film cooler is fabricated of Inconel 690 that can contain up to $11 \% \mathrm{Fe}$.[10] The metals of both components contain only a trace of Al. [10] Thus is appears that essentially all the $\mathrm{Fe}$ and $\mathrm{Al}$ in the off gas deposit results from entrainment of radioactive sludge being fed to the melter.

The ratios for $\mathrm{Fe} / \mathrm{Sr}-90$ and $\mathrm{Fe} / \mathrm{U}$ in Sample 0037, the sample from the primary off gas system also agree fairly well those in SB2 also supporting the results from the Fe/Al ratios. The Fe/Sr90 and $\mathrm{Fe} / \mathrm{U}$ ratios are higher in the Samples 0036 and 0035 (except for Sample 0035-1) suggesting segregation of these elements further down the off gas system. It appears that relatively less $\mathrm{Sr}-90$ and $\mathrm{U}$ are being carried down the off gas system compared to Fe. Perhaps, 
Sr-90 and U which are both heavier than Fe settle out faster in the off gas system than Fe. Note that this segregation was not evident for $\mathrm{Al}$ and Fe.

The results for the ratios of the concentration of Fe to the sum of the U-233, Pu-239, and U-235 concentrations are all greater than 160, the criticality safe ratio for DWPF sludge operations.[3] This ratio for Sample 0037 agrees with that measured in SB2 indicating no enhancement of fissile material in that sample. The ratios of iron to fissile are higher in the other two off gas deposits indicating depletion of the fissile material in these samples further down the off gas system. Results for all three deposits confirms that fissile material is not accumulating at these three locations in the off gas system.

The ratios involving Hg, Cs-137, and Tc-99, in Samples 0036 and 0035 are all larger than their respective ratios in SB2. The ratios involving Cs-137 and Tc-99 in Sample 0037 are also larger than the corresponding ratios in SB2. The larger ratios suggest that there is some volatilization of these elements from the melter. The presence of $\mathrm{Hg}$ in two of the off gas deposits indicates that some $\mathrm{Hg}$ had reached the DWPF melter even though $\mathrm{Hg}$ is steam stripped from the sludge in the Sludge Receipt Adjustment Tank (SRAT) process. For example, in the SB2 campaign at SRTC, it was shown that $92 \%$ of the $\mathrm{Hg}$ in the sludge had been steam stripped from sludge by the SRAT process in that campaign.[2] Apparently at least some of the Hg that reached the melter had volatilized. For Sample 0037 taken from the primary off gas line, $\mathrm{Hg}$ was not detected. This suggests that it was still volatile at this position in the off gas system. At this position, just past the film cooler, the temperature of the off gas is nominally $400^{\circ} \mathrm{C}[1]$; thus, $\mathrm{Hg}$ volatilization could still occur. The temperature at the quencher is lower, $\sim 350^{\circ} \mathrm{C}$ at the inlet and $50-100^{\circ} \mathrm{C}$ at the exit [1] and thus some $\mathrm{Hg}$ apparently condensed. It has been shown in other studies that Cs-137 and Tc-99 can be volatilized during laboratory scale melter tests $(\sim 10 \%$ for Cs-137 and $\sim 60 \%$ for Tc-99). [11] The higher ratios for Cs-137 and Tc-99 to Fe and Sr-90 than in SB2 indicate some volatilization of these radionuclides from the DWPF melter. However analyses of three glass samples taken from the DWPF melter pour stream during the SB1A campaign indicate that $93 \%$ or greater of the Tc-99 and Cs-137 are retained in the melt and solidified in the glass. [4]

Finally, the results for the Fe/Si ratios in Table 4 clearly indicate that the samples analyzed are mixtures of sludge and frit. They are not pristine sludge, pristine Frit 200, or pristine HLW glass. In SB2 sludge the ratio Fe/Si is 19.8 due to the small amount of Si present compared to Fe.[2] In SB2 glass the ratio is 0.33.[8] Apparently, molten glass with dissolved sludge is not getting from the melter to the off gas system. The ratio $\mathrm{Li} / \mathrm{Si}$ in the last row of Table 4 indicates that the deposits for some reason are depleted in $\mathrm{Li}$ or enhanced in $\mathrm{Si}$ since the ratio of $\mathrm{Li} / \mathrm{Si}$ in Frit 200 is 0.069 .[8]

\section{Hot Water Leach of Samples}

A sample of each of the off gas samples was leached with hot deionized water to determine the fraction of water soluble elements and anions that were in each of the samples. Studies made during vitrification of nonradioactive simulated sludges indicated that off gas deposits contained water soluble alkali borates, halides, and sulfates.[5,6] It was expected that if chlorides or 
fluorides were present in the radioactive off gas samples, this technique would indicate such. A known amount of each sample (approximately 0.1 grams) was put into $90 \mathrm{~mL}$ of water in a beaker (covered with $\mathrm{Al}$ foil) for 2.5 hours at $80^{\circ} \mathrm{C}$. After the heating the solutions were removed from the oven and weighed to determine the exact amount of water remaining. (Less than $10 \mathrm{~mL}$ of water was lost in each test.) All the resulting solutions still contained solids. Each solution was carefully sampled while it was still hot and then analyzed by ICP-ES and gamma counting. The solutions were also analyzed by Ion Chromatography (IC) to determine the amount of water soluble anions dissolved from the samples. After the leaching only the appearance of sample 0037 had changed while the others remained black. The black color of sample 0037 had become lighter and appeared to be dark sand. Results of the leach test were calculated in terms of weight percent of the dissolved element or anion in the original sample. This was calculated by knowing the amount dissolved element or anion (calculated from the volume of the final solution and the measured concentration of that element in the solution) and by knowing the original weight of the sample leached. The fraction of the element dissolved could then be calculated by knowing the total amount of that element in the sample from the acid dissolutions (see Tables 1-3). For this calculation the average of the respective concentrations of the elements in the samples were used (see Column 4 of Tables 1-3). Fractions of anions leached could not be calculated because the total amount of each anion in the original sample was not measured. Results are in Table 5. 
Table 5. Weight Percent of Elements and Anions Leached in Hot Water for the Off Gas Samples and the Fraction of Each Element Leached.(a)

Elements Measured by ICP-ES

Concentrations are wt. \% of soluble

element or anion in the original samples.

Element

$\begin{array}{cccc} & \mathbf{0 0 3 7}(\mathbf{b}) & \mathbf{0 0 3 6}(\mathbf{c}) & \mathbf{0 0 3 5}(\mathbf{d}) \\ \mathbf{A g} & <7 \mathrm{E}-04 & <7 \mathrm{E}-04 & <7 \mathrm{E}-04 \\ \mathbf{A l} & 5.5 \mathrm{E}-02 & 6.0 \mathrm{E}-02 & 7.8 \mathrm{E}-02 \\ \mathbf{C a} & 1.2 \mathrm{E}-01 & 7.6 \mathrm{E}-02 & 1.1 \mathrm{E}-01 \\ \mathbf{C d} & 4.3 \mathrm{E}-03 & 3.0 \mathrm{E}-03 & 4.8 \mathrm{E}-03 \\ \mathbf{C r} & 5.4 \mathrm{E}-02 & 5.2 \mathrm{E}-03 & 7.5 \mathrm{E}-03 \\ \mathbf{C u} & \text { ND } & 1.5 \mathrm{E}-04 & \text { ND } \\ \mathbf{F e} & 5.2 \mathrm{E}-03 & 6.2 \mathrm{E}-02 & 3.9 \mathrm{E}-03 \\ \mathbf{L i} & 2.0 \mathrm{E}-01 & 7.6 \mathrm{E}-03 & 1.0 \mathrm{E}-02 \\ \mathbf{M g} & 5.1 \mathrm{E}-02 & 4.4 \mathrm{E}-02 & 5.5 \mathrm{E}-02 \\ \mathbf{M n} & 4.0 \mathrm{E}-03 & 4.9 \mathrm{E}-02 & 6.0 \mathrm{E}-02 \\ \mathbf{N a} & 8.7 \mathrm{E}+00 & 8.8 \mathrm{E}-02 & 1.7 \mathrm{E}-01 \\ \mathbf{N i} & \text { ND } & 1.9 \mathrm{E}-02 & 1.5 \mathrm{E}-02 \\ \mathbf{S} & 6.1 \mathrm{E}+00 & 1.3 \mathrm{E}-01 & 2.2 \mathrm{E}-01 \\ \mathbf{S i} & 3.4 \mathrm{E}-01 & 1.1 \mathrm{E}-01 & 6.8 \mathrm{E}-02 \\ \mathbf{S n} & 1.5 \mathrm{E}-02 & 1.2 \mathrm{E}-02 & 7.7 \mathrm{E}-03 \\ \mathbf{S r} & 2.5 \mathrm{E}-02 & 1.4 \mathrm{E}-02 & 2.1 \mathrm{E}-02 \\ \mathbf{U} & 1.9 \mathrm{E}-02 & \text { ND } & \text { ND } \\ \mathbf{B} & 7.5 \mathrm{E}-01 & 3.3 \mathrm{E}-02 & 1.6 \mathrm{E}-01\end{array}$

Anions measured by IC

\begin{tabular}{cccc}
\hline Fluoride & $<0.02$ & $<0.02$ & $<0.02$ \\
Formate & $<0.08$ & $<0.08$ & $<0.08$ \\
Nitrite & $<0.08$ & $<0.08$ & $<0.08$ \\
Nitrate & 0.025 & 0.017 & 0.050 \\
Phosphate & $<0.08$ & $<0.08$ & $<0.08$ \\
Oxalate & $<0.08$ & $<0.08$ & $<0.08$ \\
Sulfate & 1.7 & 0.033 & 0.067 \\
Chloride & $<0.02$ & $<0.02$ & $<0.02$
\end{tabular}

Cs-137 Measured by Gamma Counting

$\begin{array}{lccc}\text { Concentration is uCi of soluble Cs-137 } & \\ \text { per gram of sample } \\ \text { Cs-137 } & 2.9 \mathrm{E}-02 & 1.3 \mathrm{E}-03 & 1.9 \mathrm{E}-03\end{array}$

Fraction of Element Leached

\begin{tabular}{cccc}
\hline & \multicolumn{3}{c}{ Sample Number } \\
\hline Element & $\mathbf{3 7}$ & $\mathbf{3 6}$ & $\mathbf{3 5}$ \\
$\mathbf{A g}$ & $<0.04$ & $<0.04$ & $<0.04$ \\
$\mathbf{A l}$ & $4.4 \mathrm{E}-02$ & $2.0 \mathrm{E}-02$ & $1.6 \mathrm{E}-02$ \\
$\mathbf{C a}$ & $2.0 \mathrm{E}-01$ & $1.6 \mathrm{E}-01$ & $1.9 \mathrm{E}-01$ \\
$\mathbf{C d}$ & $9.6 \mathrm{E}-03$ & $2.0 \mathrm{E}-02$ & $3.9 \mathrm{E}-02$ \\
$\mathbf{C r}$ & $3.0 \mathrm{E}-01$ & $3.2 \mathrm{E}-02$ & $5.2 \mathrm{E}-02$ \\
$\mathbf{C u}$ & NA & $9.0 \mathrm{E}-03$ & NA \\
$\mathbf{F e}$ & $1.0 \mathrm{E}-03$ & $3.3 \mathrm{E}-03$ & $2.1 \mathrm{E}-04$ \\
$\mathbf{L i}$ & $6.1 \mathrm{E}-01$ & $4.5 \mathrm{E}-02$ & $7.0 \mathrm{E}-02$ \\
$\mathbf{M g}$ & $1.1 \mathrm{E}-01$ & $7.3 \mathrm{E}-02$ & $5.7 \mathrm{E}-02$ \\
$\mathbf{M n}$ & $5.4 \mathrm{E}-03$ & $2.7 \mathrm{E}-02$ & $2.2 \mathrm{E}-02$ \\
$\mathbf{N a}$ & $7.4 \mathrm{E}-01$ & $8.9 \mathrm{E}-02$ & $1.9 \mathrm{E}-01$ \\
$\mathbf{N i}$ & NA & $5.2 \mathrm{E}-02$ & $3.5 \mathrm{E}-02$ \\
$\mathbf{S}$ & $9.3 \mathrm{E}-01$ & $1.1 \mathrm{E}-01$ & $1.9 \mathrm{E}-01$ \\
$\mathbf{S i}$ & $1.8 \mathrm{E}-02$ & $5.8 \mathrm{E}-03$ & $4.8 \mathrm{E}-03$ \\
$\mathbf{S n}$ & $6.5 \mathrm{E}-02$ & $4.2 \mathrm{E}-02$ & $2.6 \mathrm{E}-02$ \\
$\mathbf{S r}$ & $1.9 \mathrm{E}-01$ & $1.4 \mathrm{E}-01$ & $1.6 \mathrm{E}-01$ \\
$\mathbf{U}$ & $1.5 \mathrm{E}-02$ & NA & NA \\
& & &
\end{tabular}

(a) Samples were leached at $80^{\circ} \mathrm{C}$ for 2.5 hours in $\sim 80 \mathrm{~mL}$ deionized water.

(b) For sample 0037, 0.112 grams were used and the final volume of the water was $81.8 \mathrm{~mL}$.

(c) For sample 0036, 0.112 grams were used and the final volume of the water was $83.1 \mathrm{~mL}$.

(d) For sample 0035, 0.114 grams were used and the final volume of the water was $83.4 \mathrm{~mL}$. 
Several observations can be made concerning the results in Table 5. These are listed below.

- For all the samples, the elements $\mathrm{Ca}, \mathrm{Cr}, \mathrm{Mg}, \mathrm{Na}, \mathrm{S}$, and $\mathrm{Sr}$ had the highest fractions leached. The element B was detected, but the fraction dissolved could not be calculated because the amount of $B$ in the original sample was not measured. Only small fractions $(<10 \%)$ of the other elements in the deposits were water soluble. This included Si and the radionuclides U and Cs-137 where the fraction soluble was small, $2 \%$ or less for $U$ and $0.001 \%$ or less for Cs137.

- The major anion leached was sulfate in agreement with the study using simulated sludge. [3,4]

- For the sample from the primary off gas line, Sample 0037, a sizeable fraction of S and Na were soluble, $93 \%$ for the $\mathrm{S}$ and $74 \%$ for the Na. Since sulfate was detected in the leachate, at least a portion of these two elements was undoubtedly associated with the compound $\mathrm{Na}_{2} \mathrm{SO}_{4}$. This agrees with the results of analysis of soluble off gas deposits from the SGM-7 melter campaign where sulfate and sodium were identified as the most abundant water soluble species in the deposits.[5,6]

- Very little fluoride or chloride were leached. This was unexpected since soluble halide salts were detected in the off gas deposits from the melters using simulated waste. Not detecting the halide salts in the radioactive deposits may have resulted from where the samples were taken. For the samples taken from the quencher, the soluble halide salts may have already been leached by the water condensate presence in the quencher. This is supported by the fact that very little sulfate was leached from these deposits compared to Sample 0037 taken from the off gas line near the film cooler. The low amounts of soluble halide salts in Sample 0037 may have resulted from the fact that the halide salts have a tendency to be deposited further down the off gas line. [5,6]

\section{Contained X-Ray Diffraction Results}

Small samples of the solids were submitted for Contained X-Ray Diffraction (CXRD) to identify any crystalline compounds present. For Sample 0037, $129 \mathrm{mg}$ were submitted, for 0036, 318 $\mathrm{mg}$, and for $0035,141 \mathrm{mg}$. The samples were taken from the Shielded Cells in shielded bottles to reduce personnel dose rates. Still the dose rate for each sample through the bottle was nominally $600 \mathrm{mR} / \mathrm{hr}$ extremity (a dose rate at contact calculated from a reading at $4 \mathrm{~cm}$.) and 2 $\mathrm{mR} / \mathrm{hr}$ whole body (taken at $30 \mathrm{~cm}$.). The CXRD diffraction patterns are shown in Figures 2, 3, and 4. 


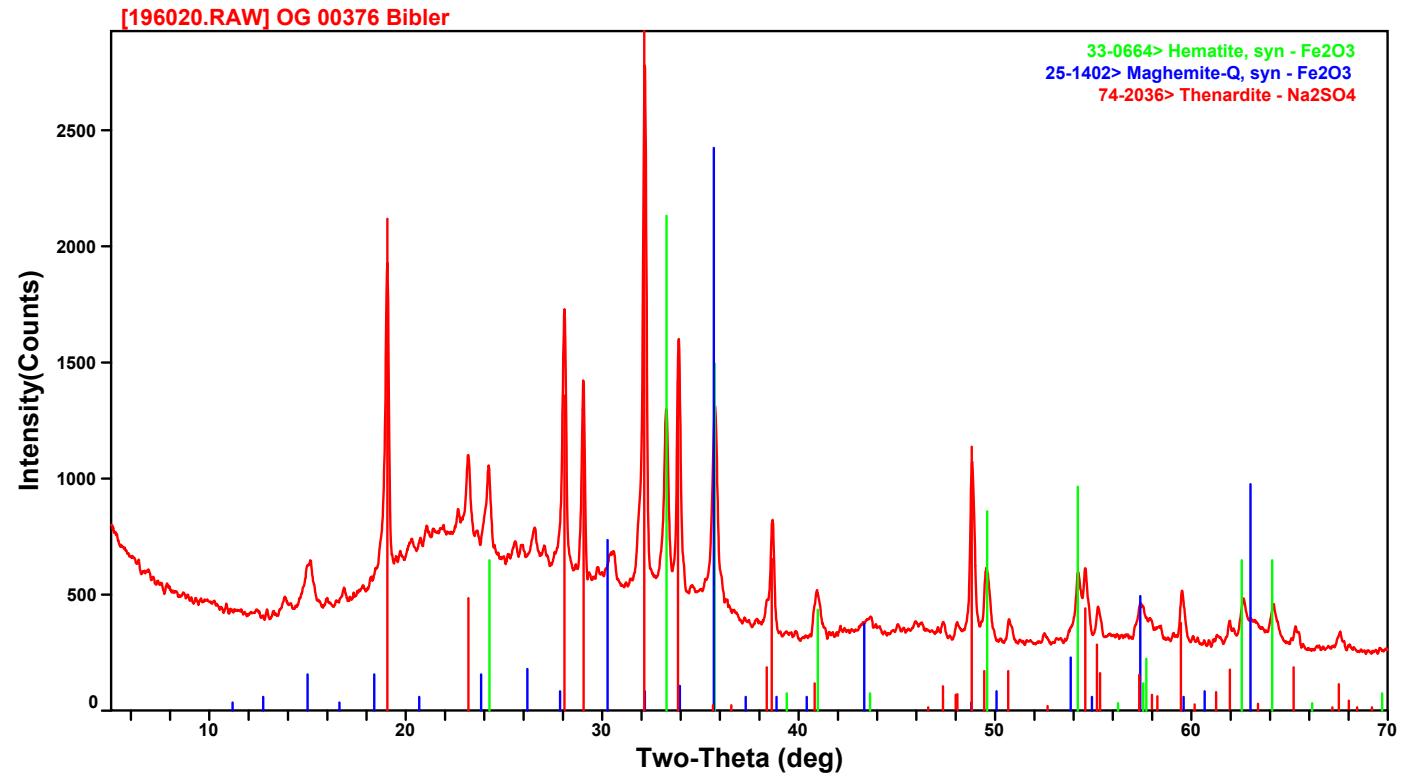

Figure 2. CXRD Pattern for Sample 0037 from the Primary Off Gas Line

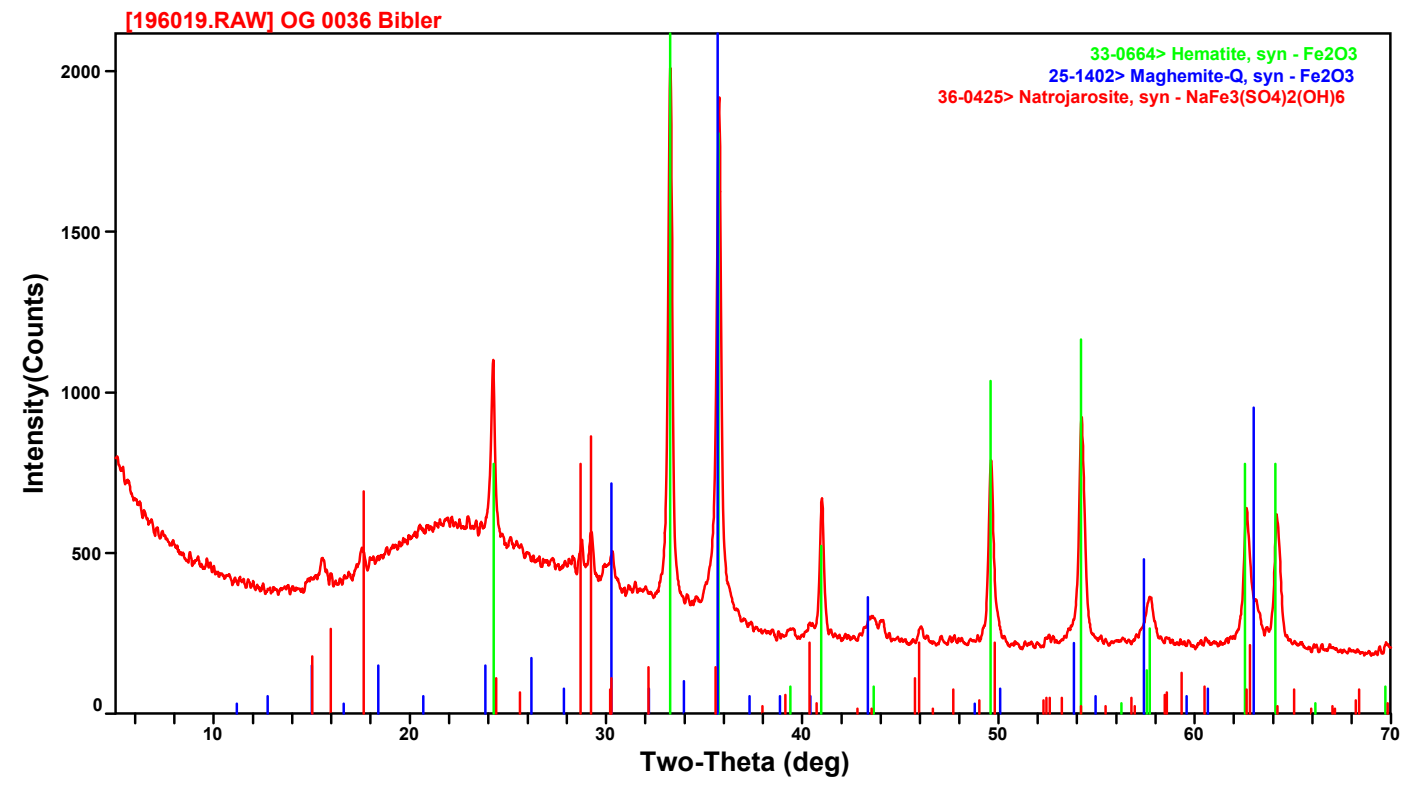

Figure 3. CXRD Pattern for Sample 0036 from the Inlet to the Quencher 


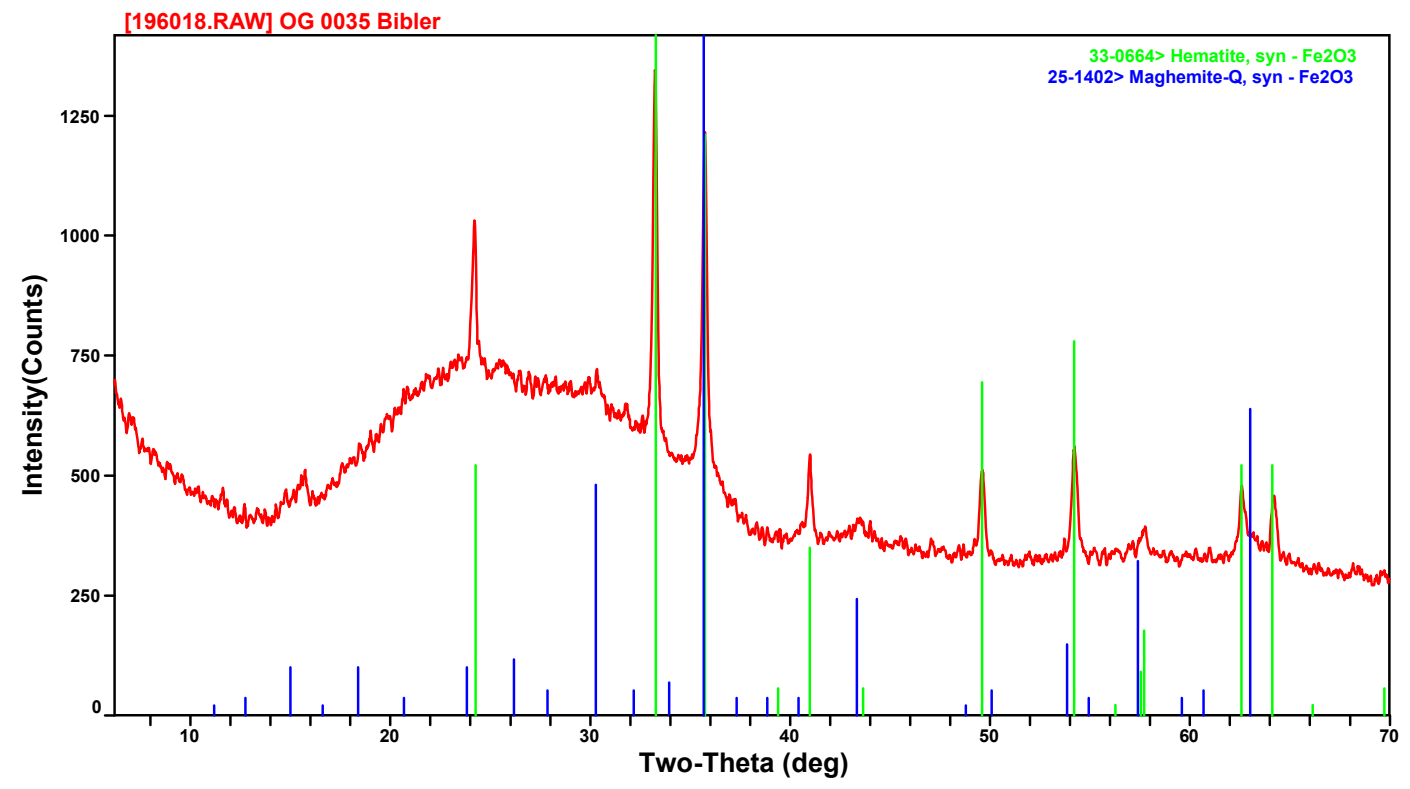

Figure 4. CXRD Pattern for Sample 0035 from the Bottom of the Quencher

The CXRD pattern for the sample from the primary off gas line (Figure 2) shows a slight amorphous hump associated with crystals of two forms of $\mathrm{Fe}_{2} \mathrm{O}_{3}$ (hematite and maghemite-Q) along with $\mathrm{Na}_{2} \mathrm{SO}_{4}$. No other crystals were detected including spinels that are usually found in devitrified SRS waste glasses. The CXRD pattern for the sample from the inlet to the quencher (Figure 3) shows a slight amorphous hump associated with the same forms of $\mathrm{Fe}_{2} \mathrm{O}_{3}$ as those in 0037 along with the compound natrojarosite which is a sulfate compound containing both $\mathrm{Na}$ and Fe. The CXRD pattern for the sample from the bottom of the quencher (Figure 4) shows an amorphous hump again associated with the same forms of Fe2O3. No sulfate compounds were detected in this sample suggesting that the sulfate compounds may have been dissolved from the deposit by condensate water from the melter. In none of the samples were patterns for $\mathrm{NaCl}$ detected as was detected in off gas samples from deposits from the melter runs with nonradioactive simulated sludges.[5,6]

\section{Contained Scanning Electron Microscopy Results}

Small samples ( $\sim 10$ milligrams) were taken from the Shielded Cells for examination by Contained Scanning Electron Microscopy (CSEM) and Energy Dispersive X-ray Analysis (EDAX). The micrographs of the three samples showed similar structure. Typical results are in Figures 5-7. 


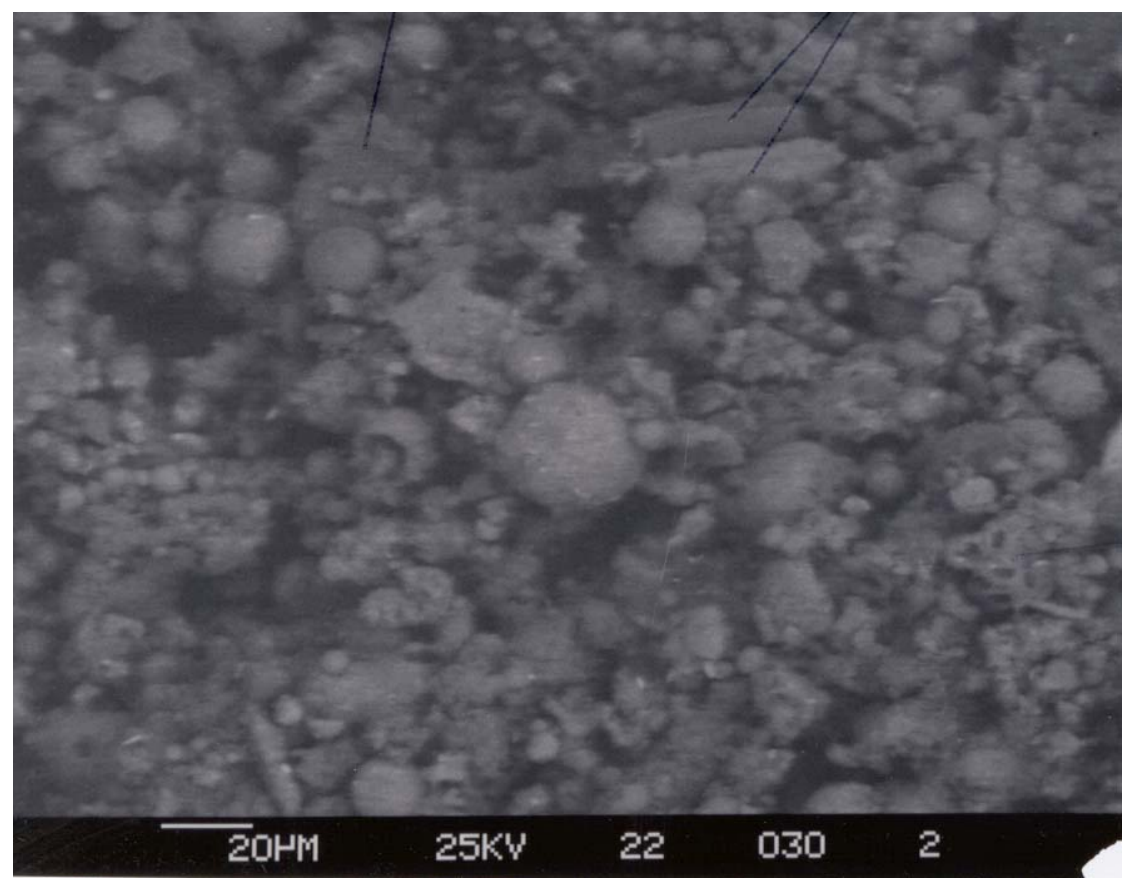

Figure 5. Typical CSEM Micrograph for Sample 0037 from the Primary Off Gas Line $($ Magnification $=500 \mathrm{X})$

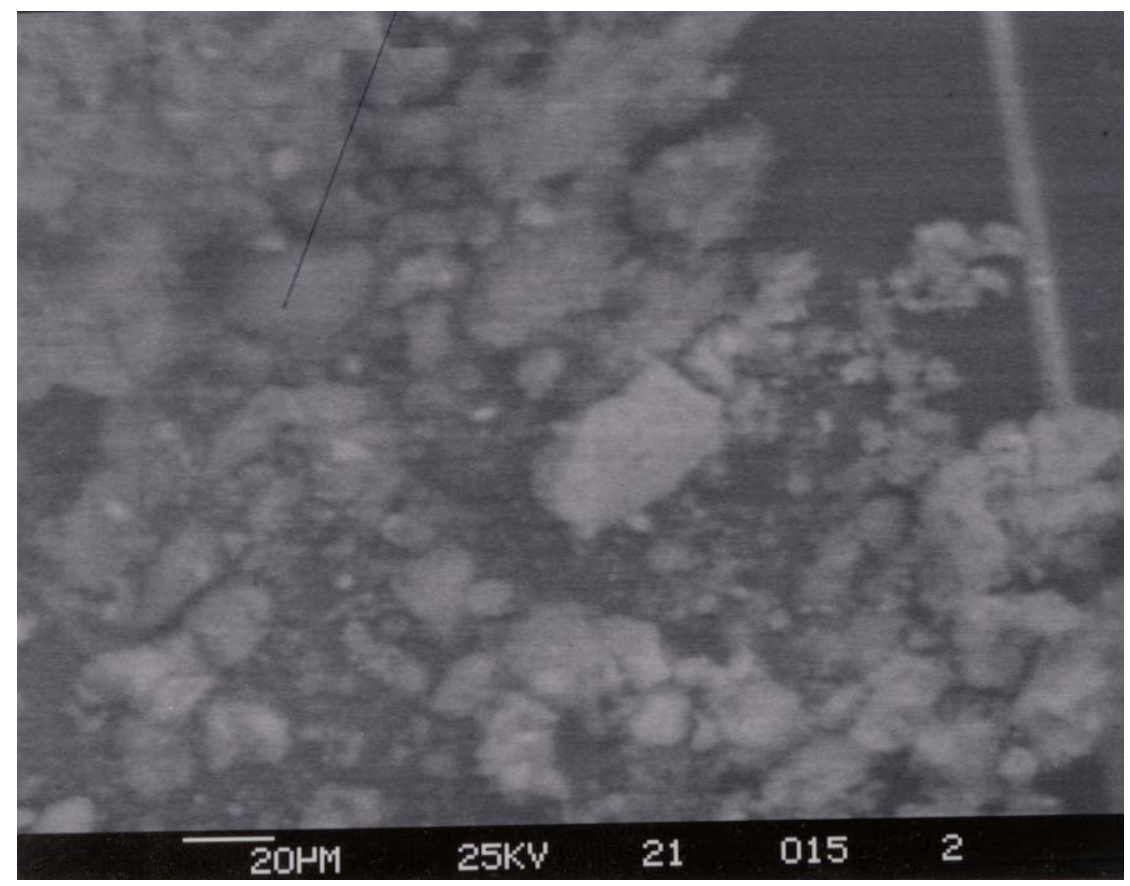

Figure 6 Typical CSEM Micrograph for Sample 0036 from the Inlet to the Quencher $($ Magnification $=500 \mathrm{X})$ 


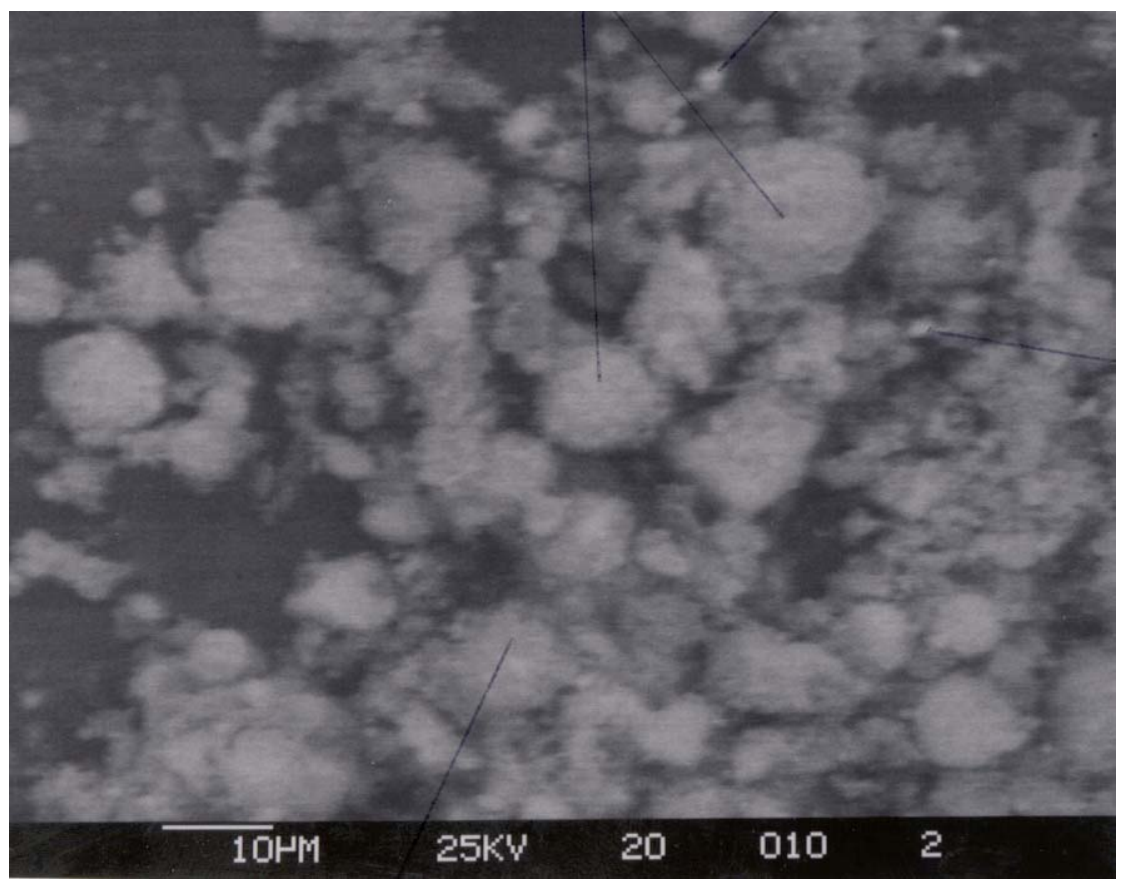

Figure 7. Typical CSEM Micrograph for Sample 0035 from the Bottom of the Quencher $($ Magnification $=1000 \mathrm{X})$

As seen in the figures, all three samples had primarily rounded particles associated with a few particles that had defined crystalline edges.

More information was obtained from the EDAX analysis. The EDAX method identifies elements from their characteristic x-rays that are emitted when the element is struck by the electron beam of the microscope. The EDAX analysis indicated that on a microscopic scale, the compositions of the samples were nonhomogeneous. As expected none of the spectra resembled that for a typical SRS waste glass where $\mathrm{Si}$ is the primary component and $\mathrm{Fe}$ is a minor component. Typical EDAX spectra for the off gas samples are shown in Figures 8-13. In all the spectra the signals for $\mathrm{Au}$ and $\mathrm{Pd}$ result from the alloy used to provide a conductive coating for the sample. 
WSRC-TR-2003-00423

Revision 0

TN-SSOE WSRC CSEM.

TLE ZQ-MAY-DZ $15: 45$

Cursor: D. QDakeV $=0$

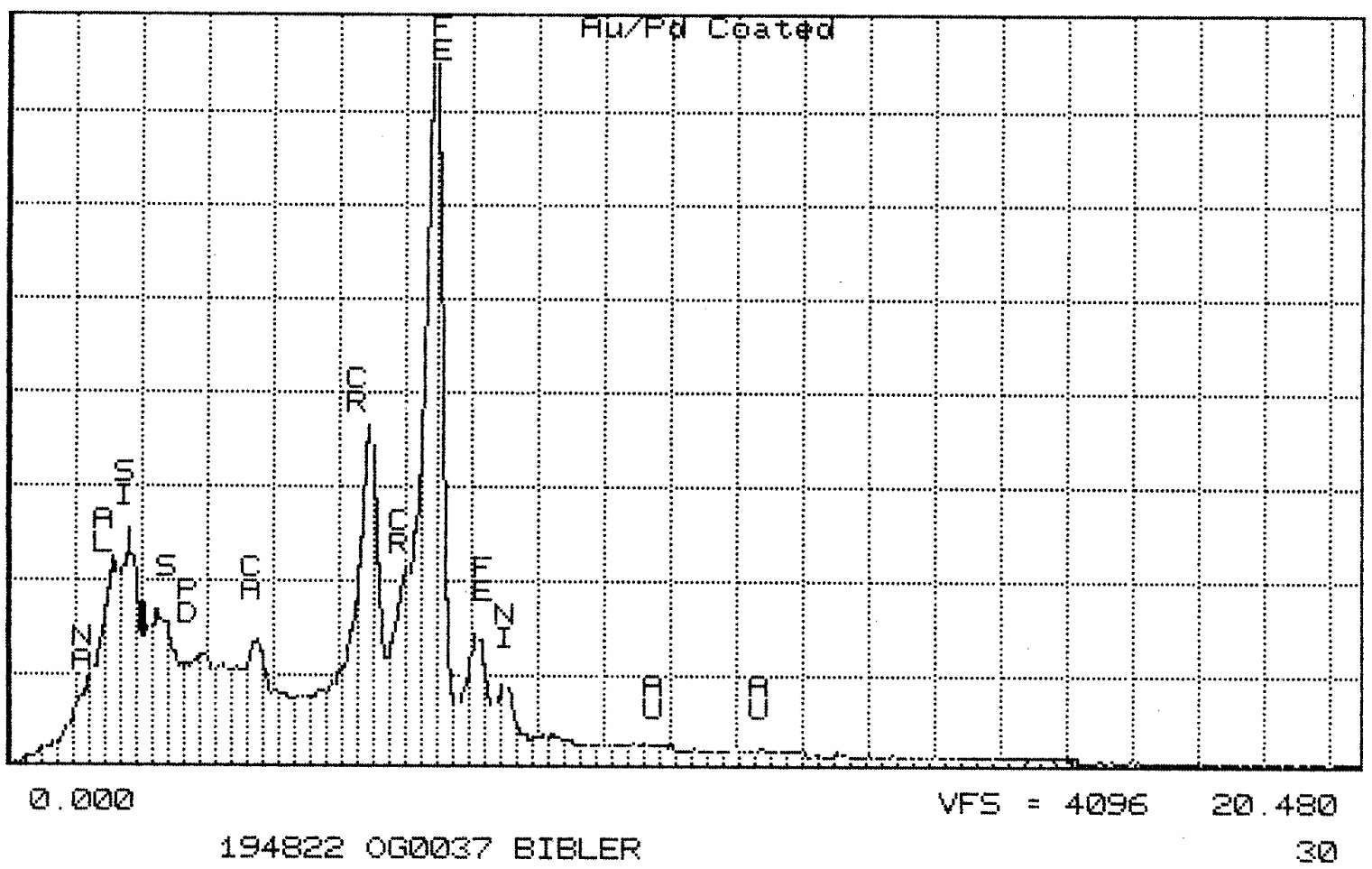

Figure 8. An EDAX Spectrum for a Particle in Figure 5 for Sample 0037 from the Primary Off Gas Line. The element Fe is a major component. (The elements Au and Pd are from the conductive alloy put on the sample.) 
WSRC-TR-2003-00423

Revision 0

TN-S5RE WSRL CSEM.

TLE $20-M F Y-03 \quad 15: 49$

Cursor: D. DQOKeV $=0$

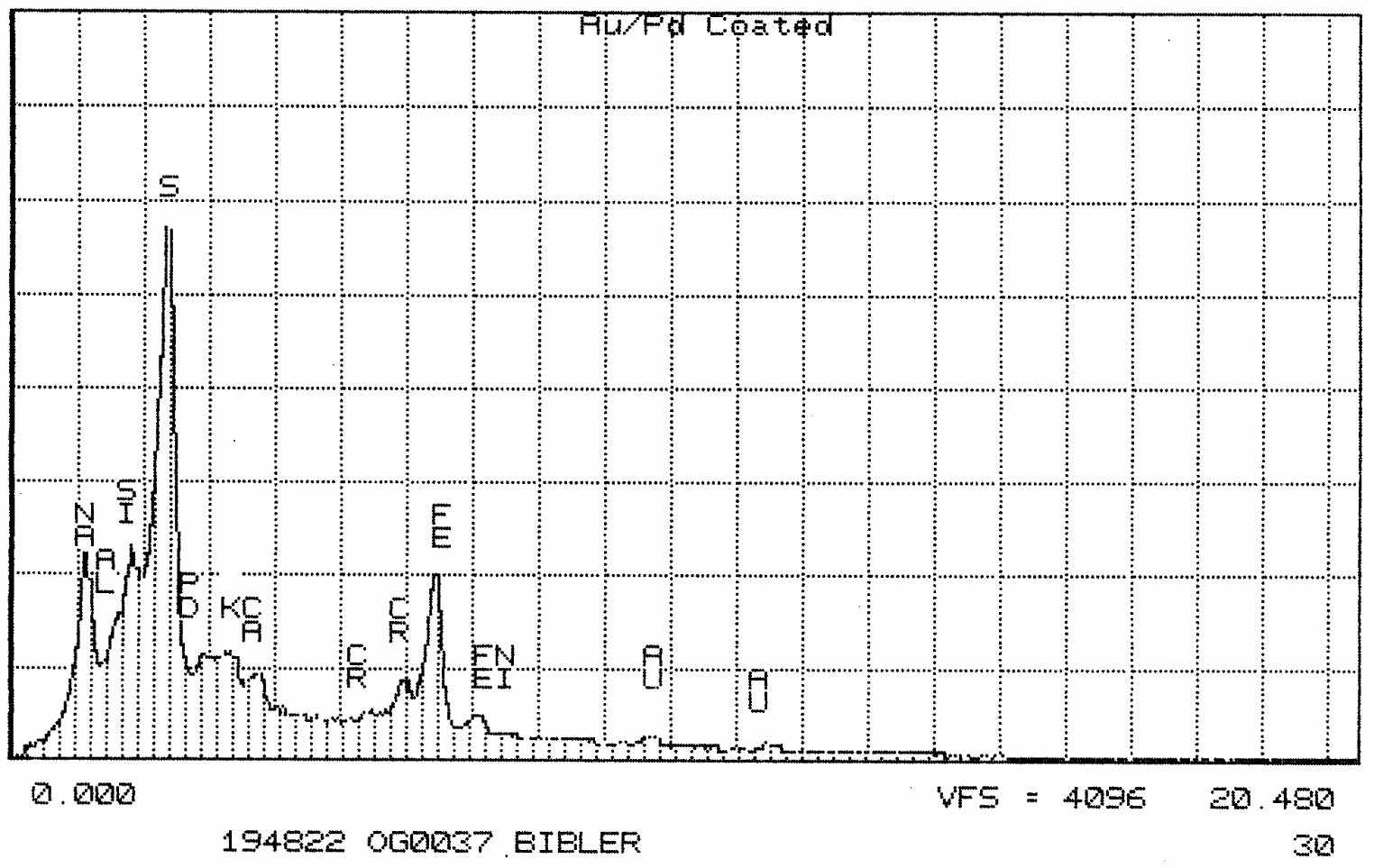

Figure 9. An EDAX Spectrum for a Particle in Figure 5 for Sample 0037 from the Primary Off Gas Line. The element $S$ is a major component. (The elements Au and Pd are from the conductive alloy put on the sample.) 
WSRC-TR-2003-00423

Revision 0

TN-SSRE WSRC CSEM.

TUE $2 Q-M F Y-Q Z S \quad 14: 21$

Eursor: Q DobkeV $=0$

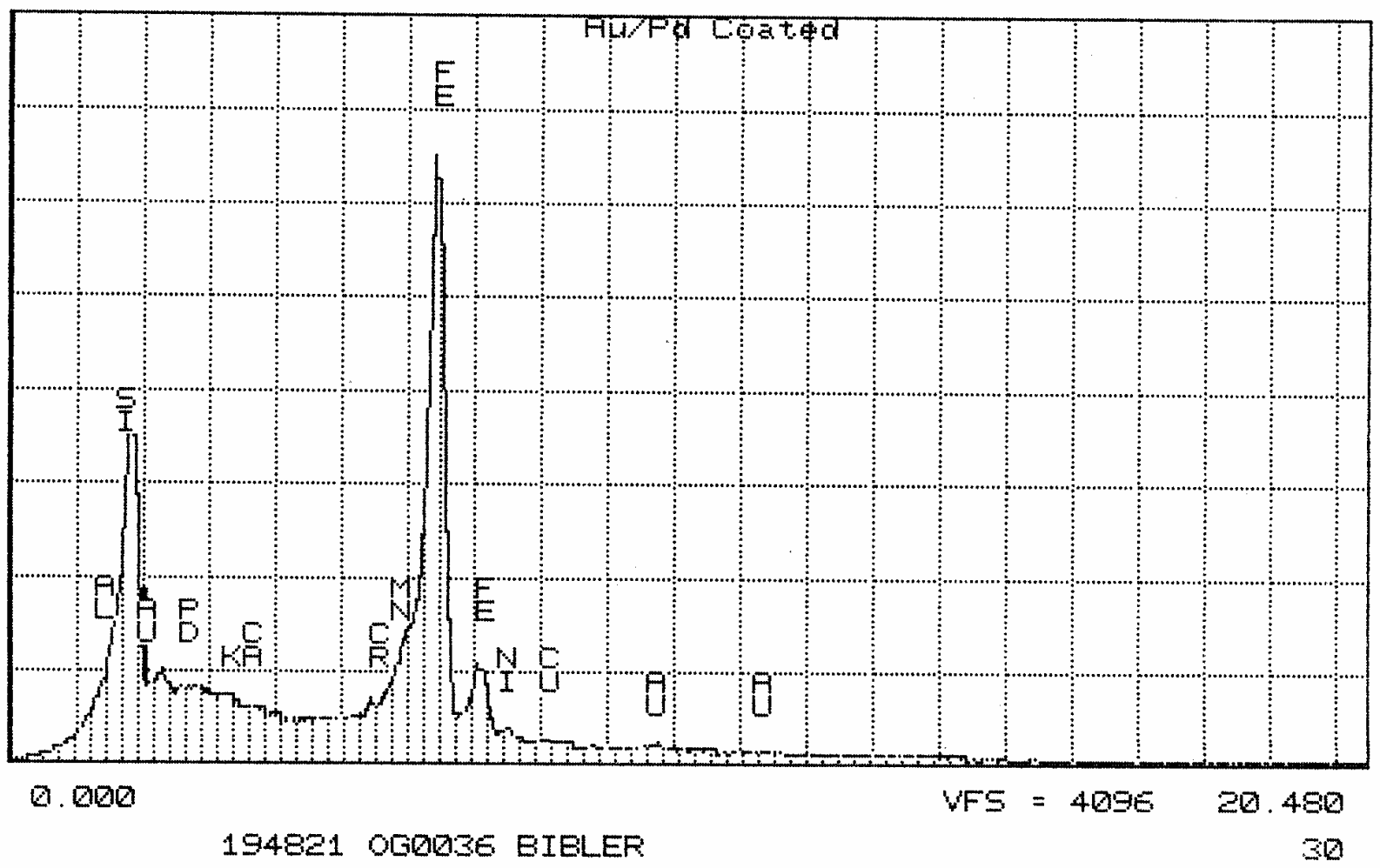

Figure 10. An EDAX Spectrum for a Particle in Figure 6 for Sample 0036 from the Inlet to the Quencher The element $\mathrm{Fe}$ is a major component. (The elements Au and Pd are from the conductive alloy put on the sample.) 
WSRC-TR-2003-00423

Revision 0

TN-550Z WSRC CSEM.

TLE ZO-MAY-OS 14:ZS

CLAR sor: Q QDQOKEV $=0$

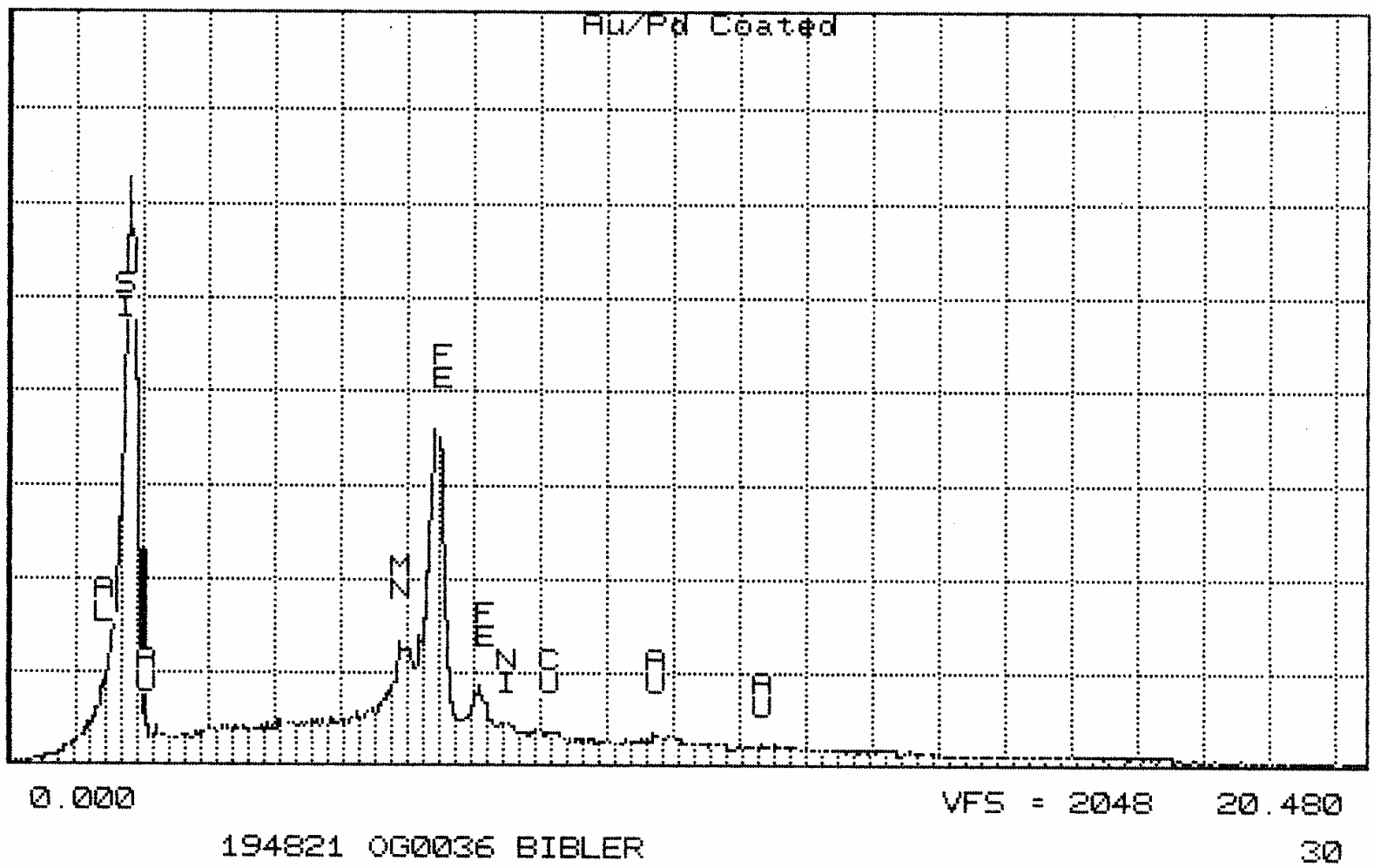

Figure 11. An EDAX Spectrum for Another Particle in Figure 6 for Sample 0036 from the Inlet to the Quencher. The element $\mathrm{Si}$ is a major component. (The elements $\mathrm{Au}$ and $\mathrm{Pd}$ are from the conductive alloy put on the sample.) 
WSRC-TR-2003-00423

Revision 0

TN-SEDE WSRC CSEM.

TLE 20-MFY-03 $095: 50$

Cursor: D. DankeV $=0$

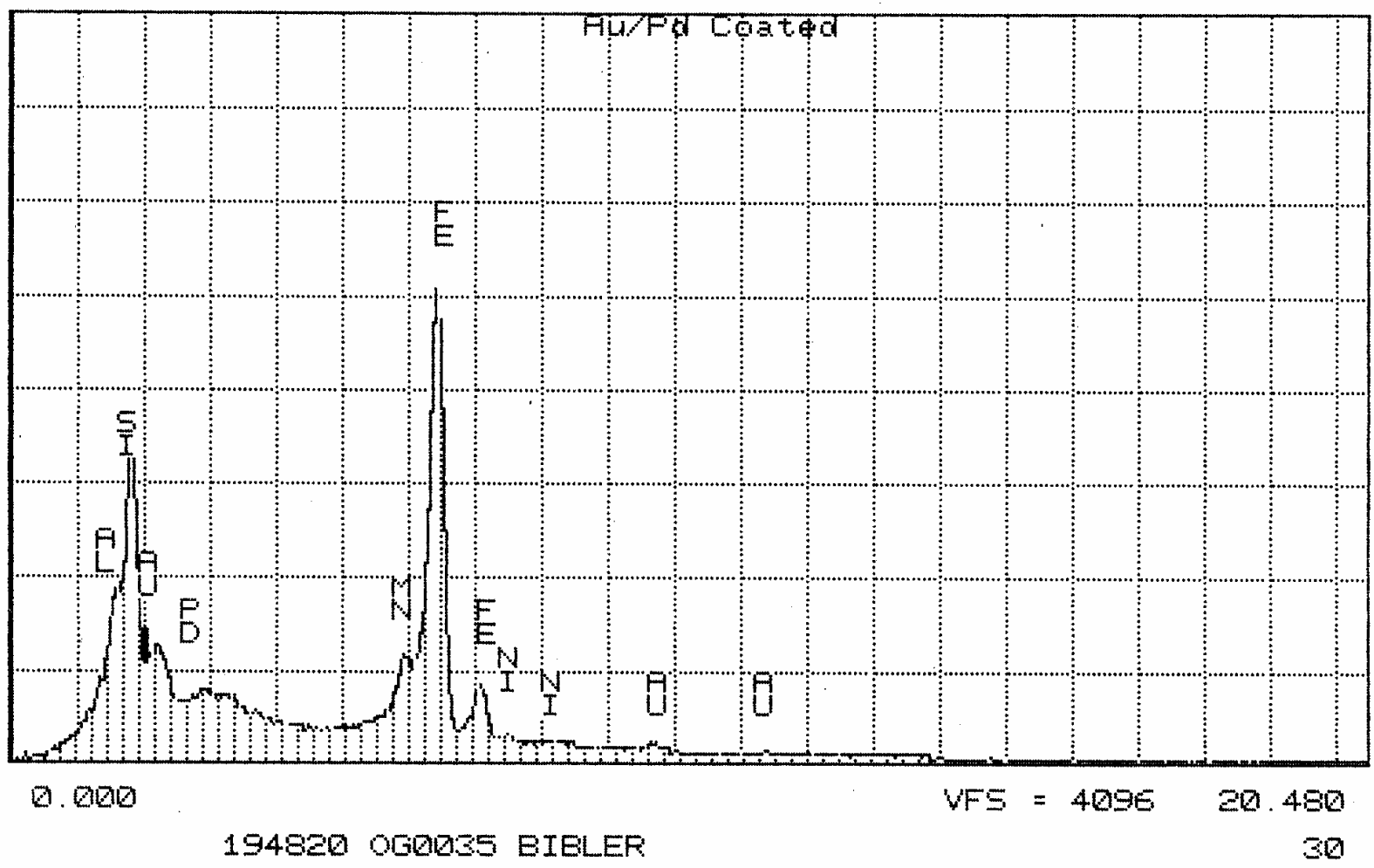

Figure 12. An EDAX Spectrum for a Particle in Figure 7 for Sample 0035 from the Bottom of the Quencher. The element Fe is a major component. (The elements $\mathrm{Au}$ and Pd are from the conductive alloy put on the sample.) 
TN-S5RZ WSFC: CSEM.

Cursor: $0.000 \mathrm{keV}=0$

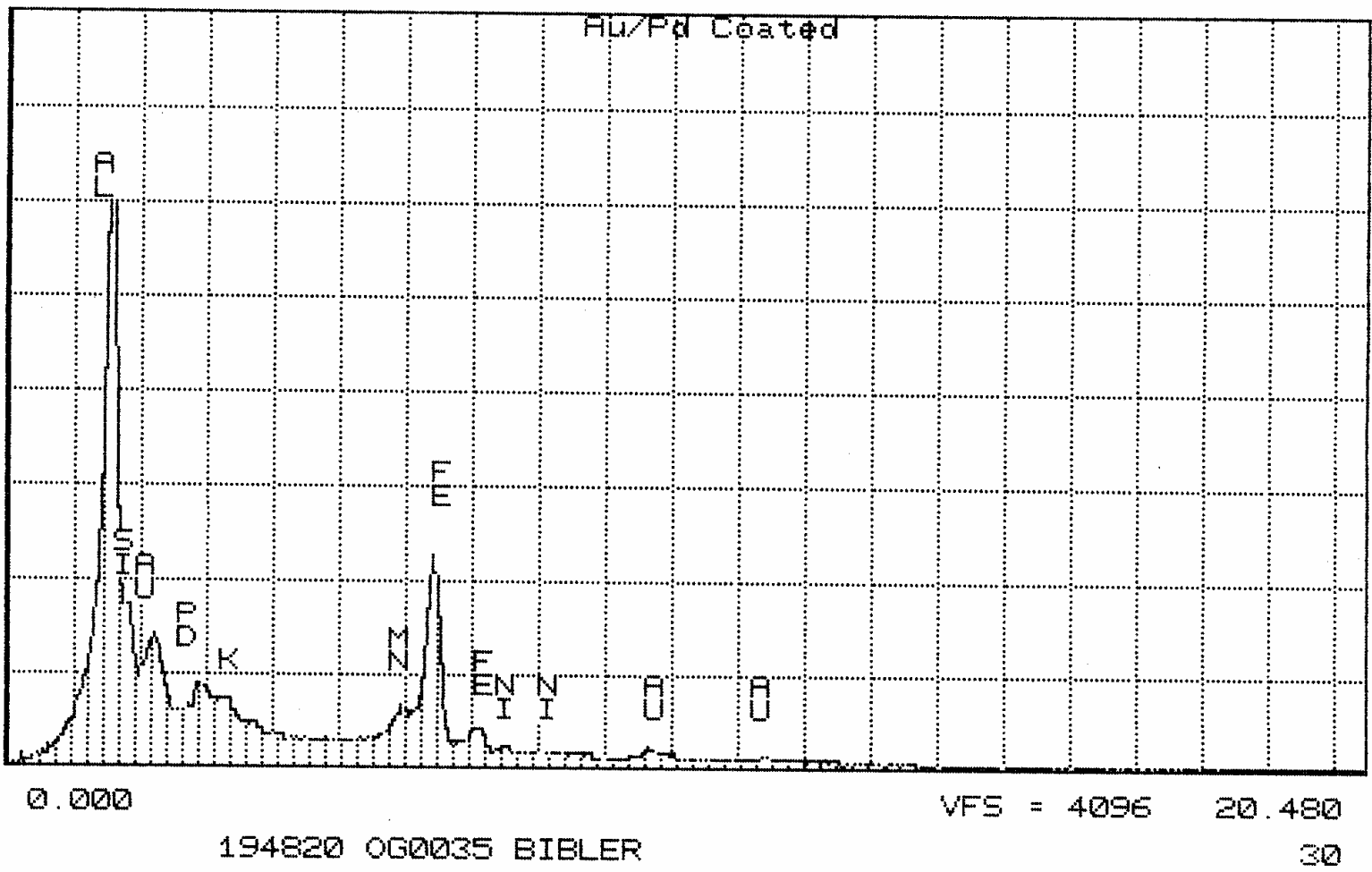

Figure 13 An EDAX Spectrum for Another Particle in Figure 7 for Sample 0035 from the Bottom of the Quencher. The element $\mathrm{Al}$ is a major component. (The elements $\mathrm{Au}$ and Pd are from the conductive alloy put on the sample.)

As seen qualitatively in Figures 9-13 the particles do not have identical compositions. This is expected since the particles are agglomerates of sludge and frit. The elements $\mathrm{Fe}, \mathrm{Si}, \mathrm{Al}, \mathrm{Na}, \mathrm{Ca}$, $\mathrm{Ni}, \mathrm{Mn}$, and some $\mathrm{U}$ were detected in all of the particles examined in all three samples by EDAX.

\section{CONCLUSIONS}

The results in this study support the following conclusions concerning the three off gas samples.

- There was no evidence for the accumulation of fissile material relative to $\mathrm{Fe}$ in the samples.

- The samples were mixtures of sludge and frit.

- Some volatilization of Hg, Cs-137, and Tc-99 from the DWPF melter had occurred. (However there is evidence that greater than $93 \%$ of the Cs-137, and Tc-99 is retained in the glass in the DWPF melter.[4] 
- Iron (III) oxide was the main crystalline compound in all three samples. The sample from the primary line also contained crystalline sodium sulfate that could be leached out of the sample by hot water. The samples from quencher contained very little sodium sulfate.

- No alkali halides, including $\mathrm{NaCl}$ were detected. This is in contrast to results for samples from off gas lines on melters using simulated sludge where $\mathrm{NaCl}$ was a main component of the samples.[5,6] However, those samples were taken at higher locations in the off gas line than the radioactive samples taken from the DWPF off gas line. 
WSRC-TR-2003-00423

Revision 0

\section{REFERENCES}

1. Personal Communication, D. C. Iverson, Process Cognizant Engineering, DWPF, September 17, 2003.

2. T. L. Fellinger, J. M. Pareizs, N. E. Bibler, A. D. Cozzi, and C. L. Crawford, "Confirmation Run of the DWPF SRAT Cycle Using The Sludge-Only Flowsheet with Tank 40 Radioactive Sludge and Fit 200 in the Shielded Cells Facility," WSRCTR-2002-00076, Westinghouse Savannah River Co., April 30, 2002.

3. J. D. Hack, 'Updated Nuclear Criticality Safety Analysis Summary Report The SArea Defense Waste Processing Facility Sludge-Only Operations (U)," WSRC-RP941132, Rev. 1, Westinghouse Savannah River Co., December, 1999

4. N. E. Bibler, T. L. Fellinger, S. L, Marra, R. J. O’Driscoll, J. W. Ray, and W. T. Boyce, "Tc-99 and Cs-137 Volatility from the DWPF Production Melter During Vitrification of the First Macrobatch of HLW Sludge at the Savannah River Site," Scientific Basis for Nuclear Waster Management VIII, Mat. Res. Soc. Symp. Vol. 44., p. 823, Materials Research Society, Pittsburg, PA, 2000.

5. C. M. Jantzen, "Glass Melter Off-Gas System Pluggages: Cause, Significance, and Remediation," WSRC-TR-90-205, Rev. 0, Westinghouse Savannah River Co., March, 1991.

6. C. M. Jantzen, "Glass Melter Off-Gas System Pluggages: Cause, Significance, and Remediation," Ceramic Transactions, Vol 23, pp. 621-630 1992.

7. “Acid Dissolution of Glass and Sludge for Elemental Analysis," ADS Procedure ADS-2227, Rev. 7, Manuel L16.1, 1/30/03.

8. T. L. Fellinger, J. M. Pareizs, N. E. Bibler, A. D. Cozzi, and C. L. Crawford, "Confirmation Run of the DWPF SME Cycle and Results of glass Analysis Using The Sludge-Only Flowsheet with Tank 40 Radioactive Sludge and Fit 200 in the Shielded Cells Facility,” WSRC-TR-2002-00096, Westinghouse Savannah River Co., June 26, 2002.

9. N. E. Bibler and J. W. Ray, "Macrobatch 3 Acceptance Evaluation - Radionuclide Concentrations in the WAQshed Sludge Slurry for Macrobatch 3 (Sludge Batch 2) (U), ' WSRC-RP-200-00970, Rev. 1, Westinghouse Savannah River Co., February 21, 2002.

10. E-Mail from K. J. Imrich to N. E. Bibler, 9/9/03.

11. H. Lammertz, E. Merz, S. T. Halaszovich, "Technetium Volatilization during HLLW Vitrification," Scientific Basis for Nuclear Waster Management VIII, Mat. Res. Soc. Symp. Vol. 44., p. 823, Materials Research Society, Pittsburg, PA, 1985. 
WSRC-TR-2003-00423

Revision 0

\section{Distribution:}

